\section{TONAL VARIATION AND CHANGE IN DIALECTS IN CONTACT: A CASE STUDY OF LAO ${ }^{1}$}

\section{Phinnarat}

\section{Akharawatthanakun $^{2}$}

\begin{abstract}
The data here are from Lao spoken by majority groups and minority groups in contact with the other Lao dialects. When Lao dialects have long been in contact with each other, it is worthwhile to investigate whether tone variation and change have occurred.
\end{abstract}

Gedney's concept of the tone box is adopted. The tone data are analyzed auditorily and acoustically. The typical distinctive tonal patterns of the Lao language are proposed. To determine how well these distinctive tones have been preserved in Lao dialects in contact, they were then compared to the ones in the Lao dialects in this study. The tonal systems of the Lao dialects are also compared to the ones in the available literature in order to find explanations for language variation.

The findings here reveal tonal variations and changes in both majority and minority Lao induced by both internal and external factors. The tonal systems of some Lao dialects differ from the patterns expected to have been derived from the typical

1 This paper is a part of the author's dissertation, Tone Change: A Case Study of the Lao Language.

${ }^{2} \mathrm{Ph}$.D. Candidate, Department of Linguistics, Faculty of Arts, Chulalongkorn University, Bangkok, Thailand. distinctive tonal patterns. Pronunciation borrowing is hypothesized as one of the important factors leading to variation and change. The patterns of tonal mergers and splits, as well as tonal characteristics, found here to be different from those in the literature, lead to the supposition of languagecontact change. The results are also helpful for identifying ethnic groups.

\section{Introduction}

\subsection{Background}

It has been generally accepted that change is one property of language. Some linguists working within particular linguistic theories have therefore attempted to accommodate the fact that language changes and to find explanations of the nature and causes of such change.

The fact of language change was widely recognized in the eighteenth and nineteenth centuries when the Neogrammarians among the historical linguists attempted to explain the sound changes in Indo-European languages. Such sound change was said to have been motivated by internal factors, i.e., mechanical and physiological factors like ease of articulation or simplification, that is, the movement toward what have been referred to as more "natural" or "less marked" forms. During the first half of the twentieth century, the structuralists suggested that external factors could also influence language change. For example, Martinet (1952, cited in McMahon, 1994: 32) notes that gaps in a system remaining empty for lengthy periods may ultimately be filled due to external factors, such as language contact. In recent years historical linguists have increasingly considered a sociolinguistic approach 
important for understanding language change. In the present paper, though one external factor, language contact, has been emphasized, internal factors have also been considered. ${ }^{3}$

Language contact has been receiving more and more attention (cf., Weinreich, 1953; Clyne 1975 cited in Salmons, 1992: 6; Ureland and Clarkson,1984; Trudgill, 1986; Thomason and Kaufman, 1988; Thomason 1997; Salmons 1992). Beyond taxonomies of languagecontact situations, some works attempt to establish hierarchies of languagecontact changes to demonstrate, for example, that lexical borrowing normally precedes phonological borrowing (cf. Clyne, 1975: 27, 52-55 (for bibliography) cited in Salmons, 1992).

In the aforementioned works, language-contact changes in different areas are investigated, such as different types of change in Scandinavian languages in contact (Ureland and Clarkson, 1984), all possible types of contact-induced change in English dialects (Trudgill, 1986), French and Norse interference in English, borrowing in Asia Minor Greek, shift-induced Uralic interference in Slavic and Baltic languages (Thomason and Kaufman, 1988), and accentual changes in the languages spoken in Early Northern Europe (Salmons, 1992).

Southeast Asia is said to be one of the areas in which there has been constant

\footnotetext{
3 The term "language contact" refers to contact on the social level, that is, contact between different dialects or languages in the same area. In other words, contact situations are those in which at least some people use more than one language (Thomason, 2001: 1).
}

contact between members of the same language families and between languages in different language families, such as Tai, Mon-Khmer, Austronesian, Sino-Tibetan, and Mong-Mien. The present study aims to describe tone variation and change in the Lao dialects ${ }^{4}$ spoken in some areas of Thailand where they are in contact.

Lao, a language in the Southwestern branch of the Tai language family $(\mathrm{Li}$, 1977) is spoken in northeastern Thailand and is the majority language of the people in the Lao People's Democratic Republic (Lao PDR). Some groups of people from the Lao PDR migrated to settle in some regions of Thailand, especially the northeast, the north, the east, and the center. In northeastern Thailand, generally known as the Isan region, Lao ("Lao Isan") is spoken by Lao people, the majority group, and various minority languages are scattered here and there. Lao is used as a lingua franca by people living in the area. Besides the northeast, Lao is also spoken in other regions of Thailand due to the fact that a lot of people from the Isan region have migrated there. It can therefore be said that in some areas of Thailand, there have been Lao people from the Lao PDR as well as Lao Isan people from the Isan region. Some groups of Lao people are in the majority in such areas, while some are in the minority.

\footnotetext{
${ }^{4}$ The term "Lao dialects" used in this paper refers to the dialects of the Lao language spoken by Lao Isan people living in several provinces of northeastern Thailand, and by Lao immigrants from the Lao PDR living in scattered groups in Thailand.
} 


\subsection{Research project}

This paper is a part of my larger research project aimed at studying the tones of several varieties of Lao with the idea of proposing three Lao subgroups: Pure Lao, Deviant Lao, and Adopted Lao. ${ }^{5}$ The difference in tones between Pure Lao and Deviant Lao is investigated in order to reconstruct the Lao proto-tonal system. Hypotheses on tone change as well as the factors motivating such changes will then be formed. Tone data for Lao dialects spoken as majority and minority dialects around Thailand and the Thailand-Lao PDR border have been collected. Other sources of possible interference are sought in the tones of the other languages spoken in the same areas.

The tone data used in this paper are partly taken from my larger study. The data here are from Loei, a Lao dialect spoken by majority and minority groups in contact with other Lao dialects: Lao Isan, Lao introduced from the Lao PDR, and Phuan.

When the Lao dialects have long been in contact with other Lao dialects that could have either the same or different linguistic characteristics, or have been in contact with other languages, it is important to learn how well the Lao proto-tonal system has been preserved. Tonal variation and change in such Lao dialects ought to be explained.

\footnotetext{
${ }^{5}$ In this study, the term "Pure Lao" refers to the Lao dialects which still preserve the distinctive tonal patterns of Lao while "Deviant Lao" refers to the Lao dialects in which there are tonal variations. "Adopted Lao" refers to the dialects/languages which are not Lao but there is confusion that they are Lao because their tonal patterns are similar to Lao's.
}

\subsection{Goal}

The tonal systems of the Lao dialects in this study have been compared to the ones in the available literature in order to find explanations for language variation and change. This paper aims to show the patterns of tone variation and change in Lao dialects spoken as majority and minority dialects in contact situations. Hypotheses on the nature and causes of tone change will also be discussed.

\section{Procedure}

\subsection{The tone-box method}

On the basis of the influences of the voicing states of initial consonants on the mergers and splits of tones in Tai dialects, the historical and comparative linguists have reconstructed for Proto-Tai, tones A $\mathrm{B}, \mathrm{C}$ in live syllables and $\mathrm{D}$ in dead syllables. William J. Gedney (1972) has proposed the "tone box", a useful method for studying tonal systems in Tai dialects. For reconstructing ProtoTai tones, he argued that vowel length in dead syllables also influenced the development of tones. His tone box consists of tones A, B, C, DL (dead syllables with long vowels), and DS (dead syllables with short vowels).

The tone box is a useful tool for studying the tones in Tai dialects, because it can give a clear picture of the patterns of tonal mergers and splits. The tone box is shown in Figure 1.

A, B, C, DL, DS refer to the tones in Proto-Tai as reconstructed by comparative and historical linguists. The Proto-Tai tones are reflected in the present Thai writing system as follows: 
Figure 1 The tone box (adapted from Gedney, 1972: 434)

\section{Proto-Tai Tone}

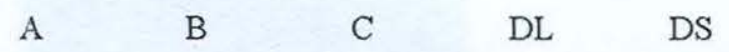

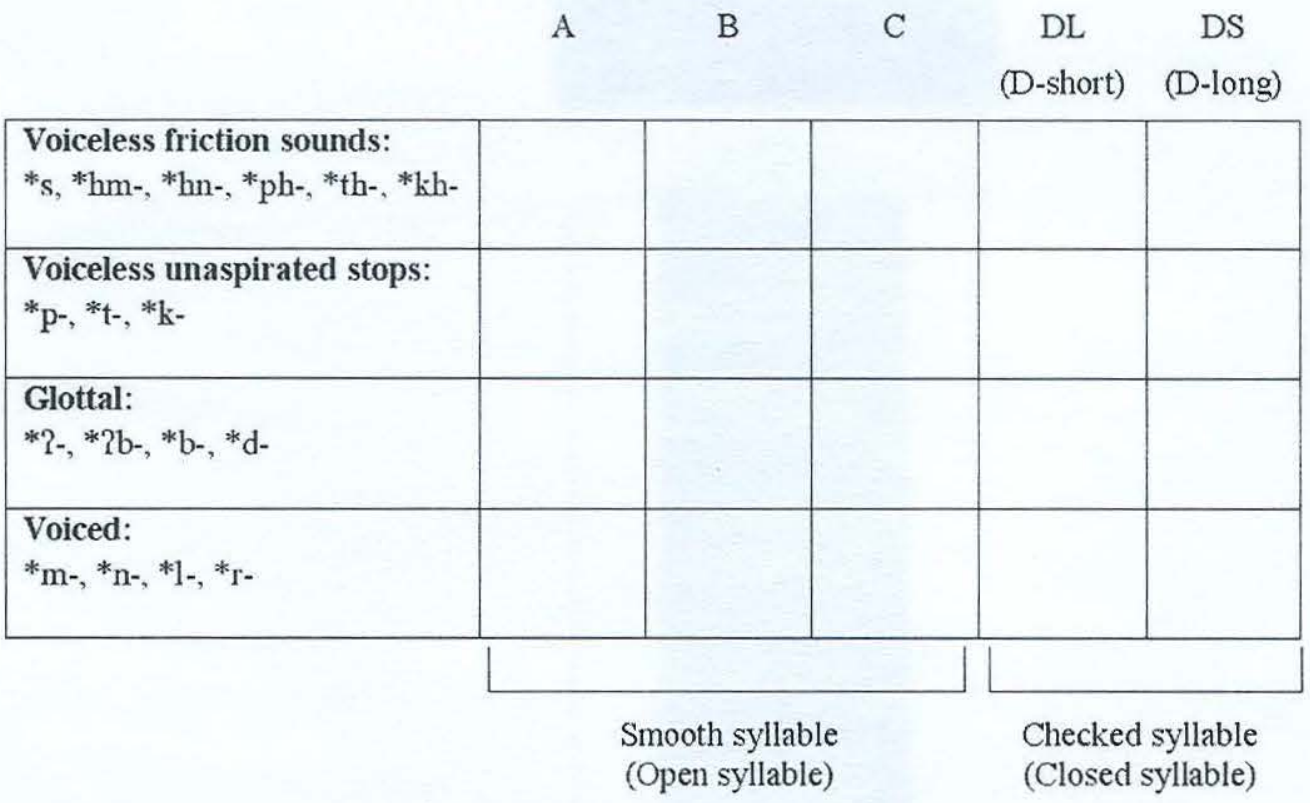

$\mathrm{A}$ is the proto-tone that occurs in a live syllable without a tone marker as in Thai, หู /hŭu/ 'ear', ขา /khăa/ 'leg', หัว /hǔa/ 'head', m /kāa/ 'crow', ปาน /pāan/ 'birth mark', ปีน /piin/ 'to climb', บาน /bāan/ 'to blossom', ดำ /dām/ 'black', มา /māa/ 'to come', ควาย/khwāay/ 'buffalo'.

$\mathrm{B}$ is the proto-tone that occurs in a live syllable with the tone marker $\left(^{-}\right)$as in, ข่า/khà/ 'ginger', ปท่ /paa/ 'forest', ปี่ /pii// 'flute', เป่า / paw/ 'to blow', บ่า /baa/ 'shoulder', ด่า/daa/ 'to scold', ค่าย /khâay/ 'camp', e่า/yâa/ 'grandmother'.

$\mathrm{C}$ is the proto-tone that occurs in a live syllable with the tone marker $\left({ }^{-}\right)$as in, ข้าว/khâaw/ 'rice', ห้า /hâa/ 'five', ป้า/pâa/ 'aunt', บ้าน /bâan/ 'house', ค้า /kháa/ 'to trade', รู้/rúu/ 'to know', ล้ม/lóm/ 'to fall'.
$\mathrm{DL}$ is the proto-tone that occurs in a dead syllable with a long vowel as in, ขาด /khaat/ 'to be torn', ผูก/phuuk/ 'to tie', ปีn/pìik/ 'wing', ปาn/paak/ 'mouth', บาด/baat/ 'to cut', ดาบ /daap/ 'sword'.

DS is the proto-tone that occurs in a dead syllable with a short vowel as in, ขัด/khat/ 'to polish', ปัด /pat/ 'to wipe', บึก/błk/ 'a kind of fish', คุก/khúk/ 'jail', คิด/khít/ 'to think', ซัก /sák/ 'to wash (clothes)'.

\subsection{Word lists}

Two word lists were used to study the tones of the Lao dialects. The first word list consists of 80 test words from a modification of Gedney's word list (see details in Gedney, 1972). That is, some of Gedney's test words were replaced by others to make the word lists suitable for investigating the dialects in question. These words can 
be used to assess the tonal systems by ear. ${ }^{6}$ The second word list consists of 20 monosyllabic words from the analogous $\operatorname{set}^{7} /$ khaa kaa paa baa(n)/, which is suitable for analyzing Tai tonal systems both by ear and through instrumental analysis. In order to get reliable results, the words from the analogous set include five tokens of each test word arranged in random order so there are 100 test words altogether $(20$ words $X 5$ repetitions $=$ 100 test words). Thus, the tone data in this study are from 7,740 test words (180 test words X 43 informants). ${ }^{8}$ The words are elicited from the informants who record them into a tape recorder.

\subsection{Typical distinctive tonal patterns of the Lao language}

In order to get a clear picture of the patterns of tone variation and change in Lao dialects in contact, the historical linguistic concept of a prototonal system is used here as the point of departure. The proto-system of any part of the phonology or the whole of it is what is reconstructed through historical and comparative analysis as the ancestor from which the systems of the daughter languages could have descended. The earlier available

${ }^{6}$ In the test words from a modification of Gedney's word list consist of different initial and final consonants, as well as different vowels. If these words are analyzed instrumentally, their fundamental frequency will be perturbed by such difference of prevocalic and postvocalic consonants, as well as vowel height. Therefore these words are more suitable for auditory but not instrumental analysis.

${ }^{7}$ The words in the analogous set consist of the same or similar initial consonants $\mathrm{k}, \mathrm{kh}, \mathrm{p}, \mathrm{b} /$ and the same vowels /aa/.

${ }^{8}$ See the test words used in this study in Appendix 1. literature was examined to obtain what appear to be the typical distinctive patterns of merger and split for the Lao language. The frequency of these patterns was the criterion for determining the probable typical tonal system. In other words, the pattern which appears in most Lao dialects will be proposed to be the ancestral or typical one of the Lao language. The same method was used to determine the typical characteristics of the tones in that system. The typical distinctive tonal patterns of Lao are shown in Figure 2. Note that the distinction between tones $\mathrm{B}$ and $\mathrm{DL}$ is presented $(\mathrm{B} \neq \mathrm{DL})$. This is an important characteristic that distinguishes Lao from some other languages in its branch of Southwestern Tai, e.g., Tai Dam, Phuan, Phuthai, and Nyo. The bold lines in Figure 2 set off the main typical distinctive patterns of tonal mergers and splits in Lao.

Figure 2 The typical distinctive tonal patterns of the Lao language ${ }^{9}$

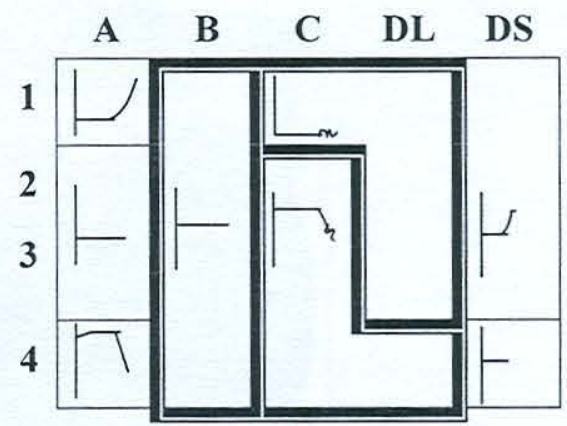
1) $\mathrm{A} 1-23-4$
2) $\mathrm{B} 1234$
3) $\mathrm{Cl}=\mathrm{DL} 123$
4) $\mathrm{C} 234=\mathrm{DL} 4$
5) $\mathrm{DS} 123-4$
6) $B \neq D L$

9 See the tonal systems and the tonal characteristics of Lao dialects/languages from the earlier literature in Appendix 2. 
From the earlier studies it is obvious that the patterns which appear most in the Lao dialects are B1234, C1=DL123, C234=DL4 and $\mathrm{B} \neq \mathrm{DL}$. As for the patterns $\mathrm{C} 1=\mathrm{DL} 123 / \mathrm{C} 234=\mathrm{DL} 4$, they are the main ones that distinguish Lao from the other Tai languages. Such patterns form a ladder; therefore, they are known as the "Lao Ladder" among scholars working in this subject area. Given these tonal characteristics, the six tones in the typical distinctive patterns of Lao are rising, high-level, high-level-falling, mid level, low level ending with a glottal stop, and highlevel-falling ending with a glottal stop. ${ }^{10}$ To determine how well these distinctive tones have been preserved in Lao dialects in contact, they were then compared to the ones in the Lao dialects in this study.

\subsection{Subgrouping of informants}

In order to see tonal variation and change as well as the patterns of tonal mixture in dialects in contact, the informants chosen for this study are both monodialectals, speaking only one Lao dialect, and bidialectals or multidialectals speaking one Lao dialect natively and another Lao dialect as their second or third dialect. Furthermore, the informants in this study are divided into two major subgroups, speakers of majority Lao dialects and speakers of minority Lao dialects. The terms majority and minority mean the relative numbers of speakers of Lao dialects in contact in the same area. There are altogether 43 informants in this study, 15 majority Lao (10 Loei, 5 Lao Isan from other

${ }^{10}$ Some tones of Lao occur with glottal stops [?] at the end, for example /khaa $11^{2}$ / in $\mathrm{Cl}$ and [khaa $443^{2}$ ] in $\mathrm{C} 234$. provinces), and 23 minority Lao (5 Loei, 10 Lao Isan from other provinces, 8 immigrants from the Lao PDR). There are also five informants for Phuan as a minority language; the tonal system of Phuan, a Tai language, will be compared with the tonal systems of the Lao dialects spoken in the same area. The subgroups of the Lao informants in this study are shown below with the numbers of them in brackets after the names of the areas where the Lao dialects are spoken. ${ }^{11}$

11 The conventional ethnic name of each group of informants outside the brackets is used; the names which the informants call themselves or are called by the other groups living in the same area are indicated in brackets. In this study, the people in Loei Province call themselves and their dialect by the names /thai ləəy/ 'ไทเลย', /laaw ləəy/ ‘ลาวเลย', or /ləəy/ ‘เลย' but they are called /thai nia/ or 'Thai Nuea' ‘ไทเหนือ' by the Lao people from other provinces, such as Nong Khai, Udonthani, Khon Kaen, Kalasin, and Chaiyaphum, because Loei Province is quite near northern Thailand. (/thai nia/ "ไท เหนือ' means the people who live in the north. Here /thai/ 'ไท' means 'a group of people' (based on the author's background and the information from people in each area) and /nia/ (เหนือ) means 'northern.') Generally, the people living in the aforementioned provinces call themselves and their language by the names /thai Piisaan/ 'ไทอีสาน', /laaw ?iisaan/ 'ลาวอีสาน', or / Piisaan/ 'อีสาน' but they are called by the people in Loei Province by the name /thai taay/ 'ไท ใต้' (the group of people who live in the southern part; /taay/ 'ใต้', which is pronounced with a falling tone, means 'southern'), and they are called by the people in the other regions of Thailand by the name "Lao" (ลาว), or "Lao Isan" (ลาว อีสาน). (According to information from the 
1) Majority Lao dialects $(15)^{12}$

1.1) Loei (Thai Nuea, Thai Loei, Lao Loei, Loei) in T. Chomsri, Chiangkhan District, Loei Province (5)

1.2) Loei (Thai Nuea, Thai Loei, Lao Loei, Loei) in T. Chiangkhan, Chiangkhan District, Loei Province (5)

1.3) Lao (Lao (Vientiane accent), Thai Tai), T. Photak, Photak Subdistrict, Nong Khai Province $(5)^{13}$

2) Minority Lao dialects (13)

2.1) Loei (Thai Nuea, Thai Loei, Lao Loei, Loei) in T. Photak, Photak District, Nong Khai Province (5)

2.2) Lao immigrants from the Lao $\mathrm{PDR}^{14}$ in T. Chomsri, Chiangkhan District, Loei Province (3)

2.3) Lao immigrants from the Lao PDR in $T$. Chiangkhan, Chiangkhan District, Loei Province (5)

3) Other minority dialects $(15)^{15}$

3.1) Lao Isan (Thai Isan, Lao Isan, Isan, Lao, Thai Tai) immigrants from other provinces in $\mathrm{T}$. Chiangkhan, Chiangkhan District, Loei Province (5)

informants in my pilot studies as well as in this study, and from my background as a native speaker of Lao, some people in the Isan region prefer being called "Thai Isan" or "Lao Isan" to being called "Lao", as for them "Lao" is the name which they use for the Lao people in the Lao PDR. Thus, some of them will identify themselves by the name "Thai Isan" or "Lao Isan" instead, while some, including me, have no problem with being called "Lao").

${ }^{12} \mathrm{~T}$. = Tambon, a subdistrict.

13 The tonal systems of other minority dialects will be presented in Appendix 2 .

${ }^{14}$ Lao immigrants from the Lao People's Democratic Republic.

${ }^{15}$ The tonal systems of other minority dialects will be presented in Appendix 2.
3.2) Lao Isan (Thai Tai) immigrants (from other provinces) in $\mathrm{T}$. Chomsri, Chiangkhan District, Loei Province (5)

3.3) Phuan in T. Photak, Photak District, Nong Khai Province (5)

\subsection{Analysis}

The tone data in this study were analyzed in two ways, by auditory analysis and instrumental analysis. The tonal mergers and splits were determined by ear, and the tonal characteristics were analyzed with the SIL CECIL program (Summer Institute of Linguistics Computerized Extraction of Components of Intonation in Language). Eighty test words modified from Gedney's word list were analyzed by ear and used to assess tonal mergers and splits; moreover, 100 test words from the analogous set were analyzed both by ear and by extraction of fundamental frequency values. The results of the two approaches form the basis of all descriptions here whether given verbally, as tone sticks, or as points on a numerical scale.

\section{Results}

\subsection{Variations and changes in patterns of tonal mergers and splits}

To come to conclusions concerning variation and change in majority and minority Lao dialects, the tonal patterns of Lao from earlier literature are compared to the patterns found in this study. In a comparison with Loei in Brown (1965) of majority and minority dialects spoken in two subdistricts of Loei Province, the degree of similarity of patterns of tonal mergers and splits among these 
three sources is shown in Figure 3. ${ }^{16}$

Figure 3 indicates that in $\mathrm{T}$. Chiangkhan there are four tonal patterns. Pattern (1), for which there are two speakers, has the same tonal patterns as Brown (1965), while patterns (2), (3), and (4) do not. It can be tentatively concluded that the main patterns of majority Loei in this subdistrict are A1-234, B1234, $\mathrm{C} 1=\mathrm{DL} 123, \mathrm{C} 234=\mathrm{DL} 4^{17}$, and DS1234 , but in tonal patterns (2), (3), and (4), variations are mostly found in tone A. More variations are found in pattern (3) than in the others, in particular, variation of the "Lao Ladder" pattern. In pattern (4), it can be clearly seen that the tonal patterns of this speaker show change, i.e., the pattern $\mathrm{Cl}=\mathrm{DL} 123$ ("Lao Ladder"), one of the main patterns of $\mathrm{Lao}$, changes to the $\mathrm{Cl} \neq$ DL123 pattern. In majority Loei spoken in T. Chomsri, the degree of variation is higher than in majority Loei of $\mathrm{T}$. Chiangkhan. As can be seen in Figure 3, there is only pattern (1) which still preserves the "Loei tonal patterns" as in Brown (1965), while the others show variations in tones $\mathrm{A}, \mathrm{B}, \mathrm{C}$, and DS. Pattern (5) in T. Chomsri and Patterns (4)\&(5) in T. Photak also shows change of $\mathrm{Cl}=\mathrm{DL} 123$ to $\mathrm{Cl} \neq$

\footnotetext{
${ }^{16}$ The number in brackets below each tone box represents the pattern of tonal mergers and splits, for example, (1) = Pattern 1, (2) $=$ Pattern 2, and so on. The name of the informant appears after each such number. Within each tone box, the solid lines show the splits of tones, while the dashed lines show that the splits cannot be judged as there are variants of those tones. That is, within any cell separated by a dashed line, there may be a variant that is much the same as a variant in a neighboring cell, implying a possible merger of two tones.

17 Patterns $\mathrm{Cl}=\mathrm{DL} 123$ and $\mathrm{C} 234=\mathrm{DL} 4$ constitute the "Lao Ladder" (see section 2.3).
}

DL123, as in pattern (4) of $\mathrm{T}$.
Chiangkhan.

The split between $\mathrm{Cl}$ and DL123 of the speaker with tonal pattern (4) of T. Chiangkhan, the one with pattern (5) of T. Chomsri seems to have been motivated by internal factors. That is, tones DL123 in both patterns are expected to be mid- rising-falling [353s] or high-rising-falling [453] like tone $\mathrm{C} 1$, but in fact such tones are changed to high-level [344]/[44]. Thus it is suspected that the contour tones, mid-rising-falling or high-risingfalling, in both speakers have been simplified to a level tone. More evidence related to this issue will be shown in the section on tonal characteristics.

As for the minority Loei spoken in T. Photak, the complete tonal pattern of Loei (Brown, 1965) is found only in pattern (1). Variations mostly occur in tone $\mathrm{A}$, as can be seen in patterns (2) and (3). The "Lao Ladder" pattern is still preserved in patterns (1), (2), and ( 3 ) but changed to $\mathrm{C} 1 \neq \mathrm{DL} 123$ in patterns (4) and (5). The phenomenon of change is a kind of mixture between two dialects, i.e., tone $\mathrm{Cl}$ of these two speakers is high-falling, which is borrowed from Standard Thai, while tones DL123 are still high-level as in the other minority Loei speakers. Such change causes the split between $\mathrm{Cl}$ and DL123 as shown in Figure 3. It can then be concluded that the change found in the tonal patterns of these two minority Loei speakers is motivated by an external factor, language contact between Loei and Standard Thai. Almost all Thai people are bidialectal, speaking a regional dialect and Standard Thai, which is based on the Central Thai dialect of the central region around Bangkok, 
Figure 3 Comparison of the tonal systems of majority Loei, minority Loei, and Loei in earlier literature

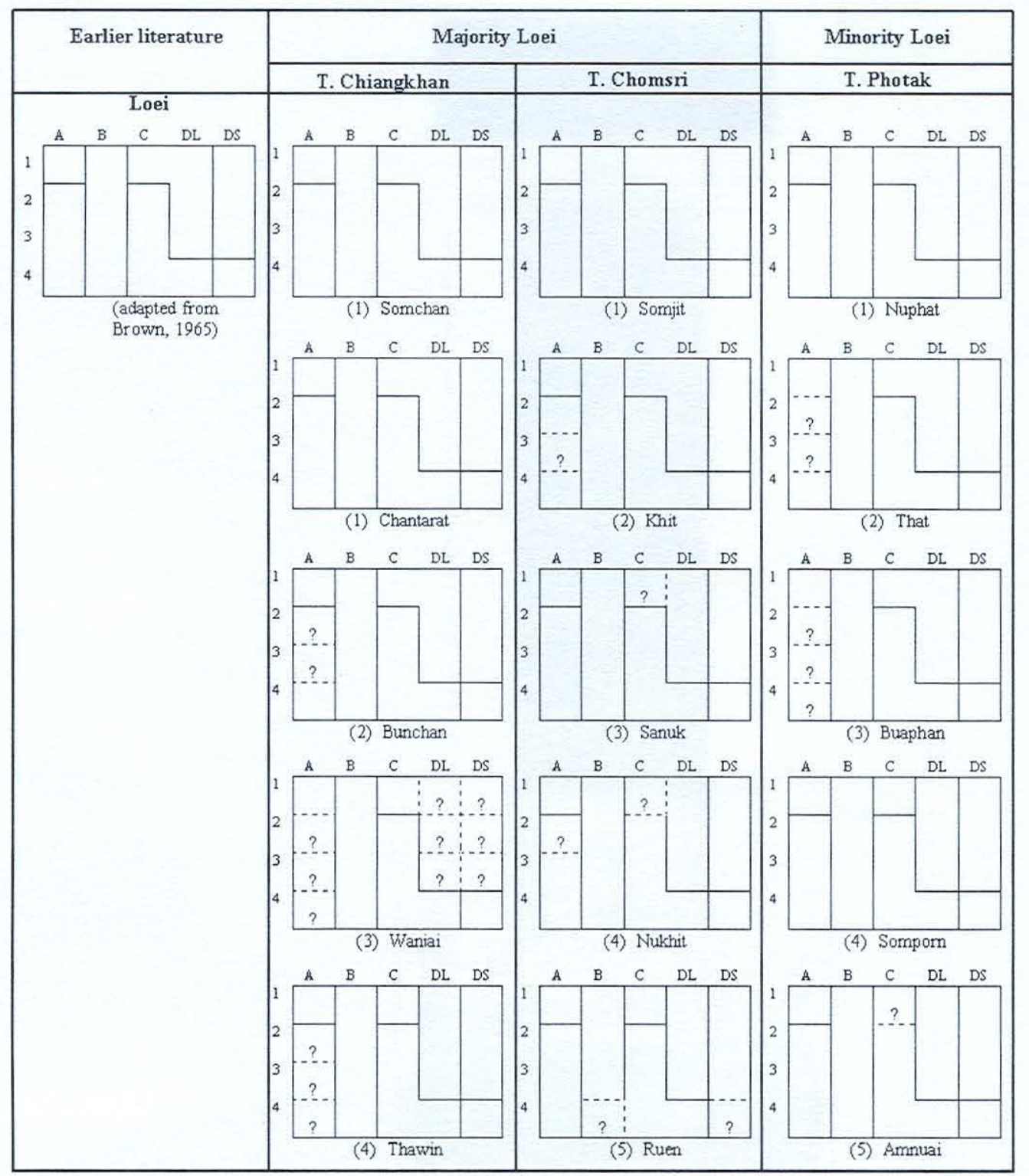

the capital. ${ }^{18}$

Evidence of linguistic change motivated by external factors is also found in the

18 Although our Loei speakers are most generally in contact with local varieties of colloquial Central Thai, they are also exposed, more or less, to its socio-linguistic variety known as Standard Thai through the schools, radio, and television. case of minority Lao dialects spoken by Lao immigrants from the Lao PDR who live in northeastern Thailand. The immigrants whose tones are investigated in this study live in the same area as the majority Loei of T. Chiangkhan and $\mathrm{T}$. Chomsri. In Figure 4 a comparison of the tonal patterns of minority Lao immigrants to those in the earlier literature shows variation and change. 
Figure 4 Comparison of the tonal systems of minority Lao from the Lao PDR and earlier literature

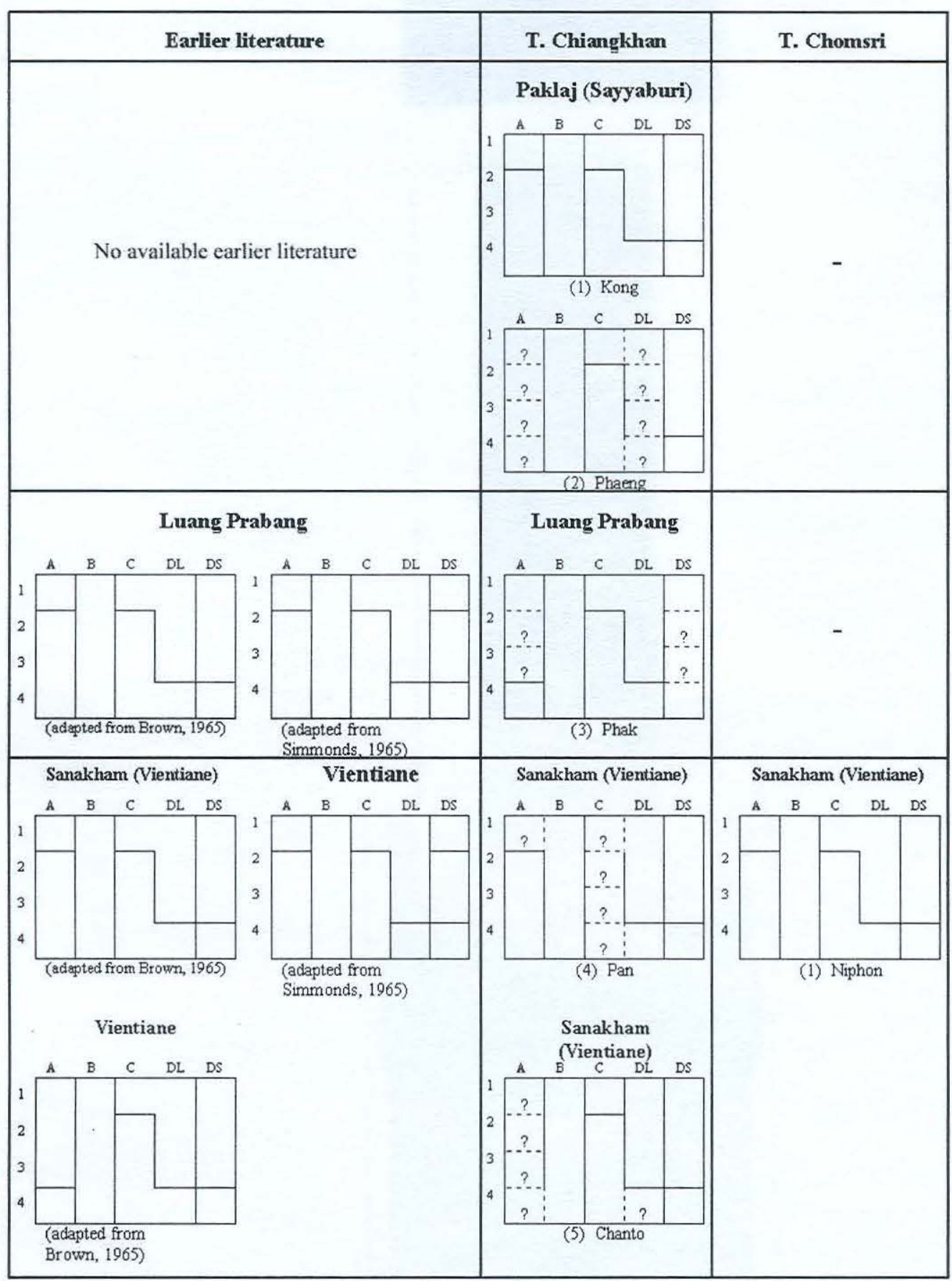


Figure 4 (continued)

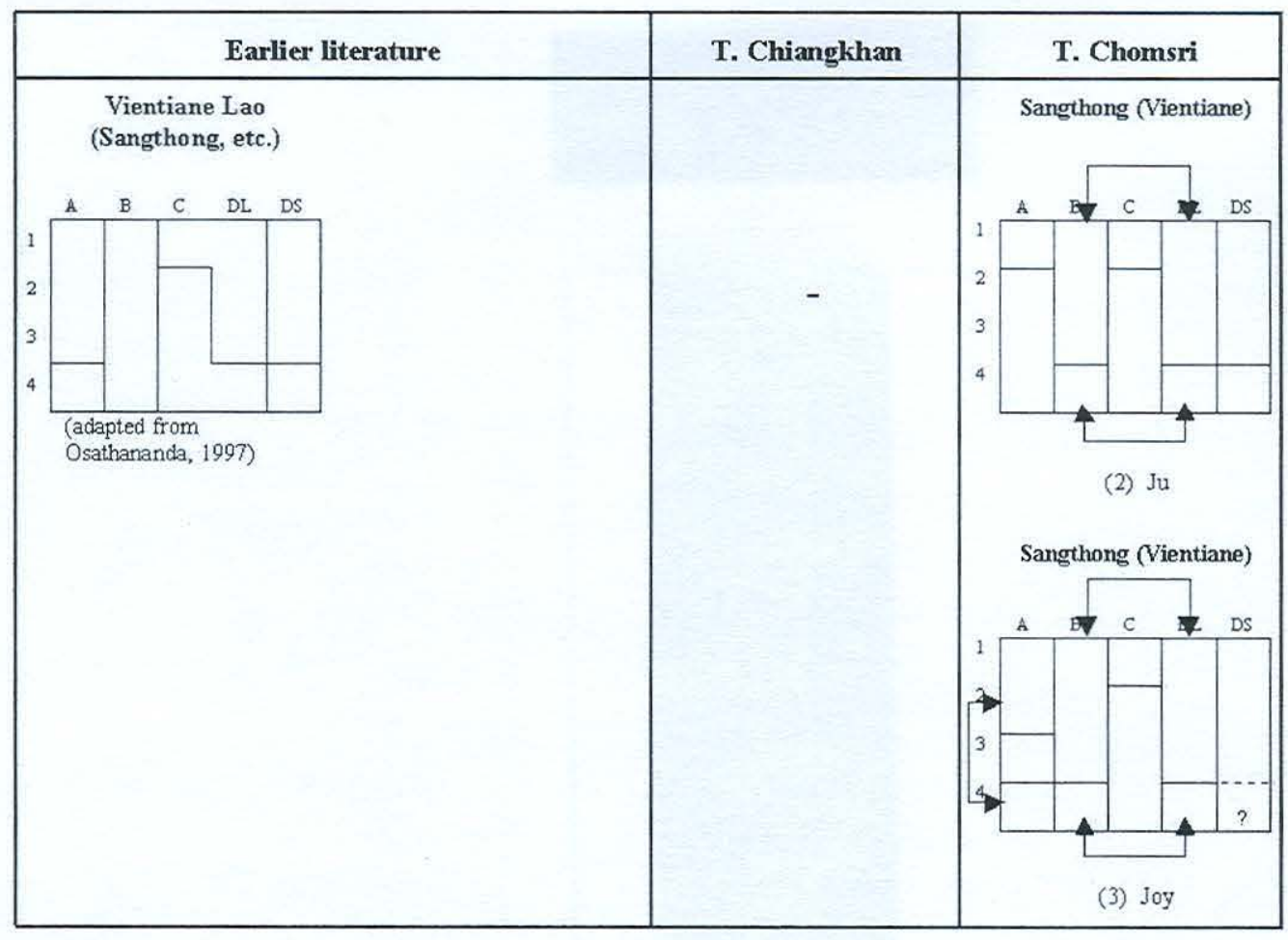

As can be seen in Figure 4, tonal variations have mostly occurred in tone $\mathrm{A}$, as in majority Loei and minority Loei. Patterns (1) and (2) of Paklaj of Sayyaburi in T. Chiangkhan would be expected to have the same pattern of tonal mergers and splits, but pattern (2) shows variations in tone A and DL. By the way, it cannot be concluded that there is no change in pattern (1) of Paklaj, Sayyaburi, because there is no available literature to be compared to. It has the same patterns of mergers and splits as pattern (1) of majority Loei spoken in the same area (see Figure 2). Thus it may be possible that the tones of minority Paklaj, Sayyaburi have been influenced by majority Loei. More data are needed for making conclusions about this issue.

As for the tonal patterns of minority Luang Prabang with its pattern (3),
Figure 4 indicates variations and changes in tone A, especially the split between $\mathrm{A} 3$ and $\mathrm{A} 4$, while in Luang Prabang of Brown (1965), and Simmonds (1965) there is no split between $\mathrm{A} 3$ and $\mathrm{A} 4$ but between $\mathrm{A} 1$ and $\mathrm{A} 2$ (A1-234). It is suspected that such a change of tone A in minority Luang Prabang may have happened under the influence of Lao Isan spoken by a minority group in the same area with the A1-23-4 pattern. ${ }^{19}$

As for the Lao language of Lao immigrants from Sanakham City in Vientiane Province, the mergers and splits of tone A of the three speakers, two in $\mathrm{T}$. Chiangkhan and one in T. Chomsri, show clear variations and changes. Tone A in pattern (4) of

19 See the tonal patterns of mergers and splits of Lao Isan spoken in $T$. Chiangkhan in Appendix 3. 
T. Chiangkhan and pattern (1) of T. Chomsri splits between $\mathrm{A} 1$ and $\mathrm{A} 2$ (A1-234), which is completely different from the earlier literature (A1-23-4 in Osathananda (1997) and Simmonds (1965), A123-4 in Brown (1965)). Furthermore, the Lao Ladder is not preserved in pattern (5) of Sanakham, Vientiane of T. Chiangkhan in which there are also variations of tone A to a high degree.

The more interesting case is found in T. Chomsri, where Lao Sangthong from Vientiane is spoken. Lao Sangthong, Vientiane shows completely different patterns of tone mergers and splits from those of the earlier literature. Even though both speakers (patterns (2) and (3)) identify themselves as speakers of Lao, it is suspected that they are in fact speakers of Phuan, a Tai language spoken in some areas of northeastern Thailand (but not in the same area as Lao Sangthong speakers). The comparison of the patterns of tonal mergers and splits between Lao Sangthong of Vientiane and Phuan will be discussed in the Conclusion and Discussion section.

\subsection{The variations and changes of tonal characteristics}

\subsubsection{Majority Loei and minority Loei}

It is found in this study that there are variations and changes of tonal characteristics of majority Loei, minority Loei, and minority Lao immigrants from the Lao PDR spoken in language contact situations. These variations and changes affect the patterns of tonal mergers and splits mentioned in Section 1. Two criteria are used to judge whether there is variation or change in a tone of a speaker. (1) If in five utterances of a word a speaker uses more than one tone and such tones are not the same as the ones in the literature, it is assumed that variation of the earlier tone has occurred. (2) If a speaker consistently utters a word with a tone that is altogether different from that of other speakers of the same dialect and that differs from the literature, it is concluded that a change has taken place yielding, in this respect, subdialects.

Based on such criteria, the variations and changes of tonal characteristics of majority Loei and minority Loei can be seen in Table 1 and those of Lao immigrants from the Lao PDR in Table 2.

As can be seen in Table 1, the variations of majority Loei and minority Loei are found mostly in tone A, especially tones A234, which are considered to have been influenced by both internal and external factors. Tone $\mathrm{Cl}$ of some speakers in both groups is also varied but to a lesser degree than tones A234. When comparing each tone of these two groups of Loei speakers with Brown (1965), it is found that only tones B1234, C234/DL4, and DS4 in the speech of most Loei speakers have the same characteristics as in Brown. The variations and changes of these three groups of Loei speakers are described below.

\subsubsection{Majority Lao Loei in $\mathrm{T}$. Chiangkhan}

Tone $\mathrm{Al}$ of all five majority Loei speakers in T. Chiangkhan is found to be rising, which is obviously different from the falling Tone Al of Loei in Brown (1965). Tone Al of minority Lao Isan people (migrants from the 


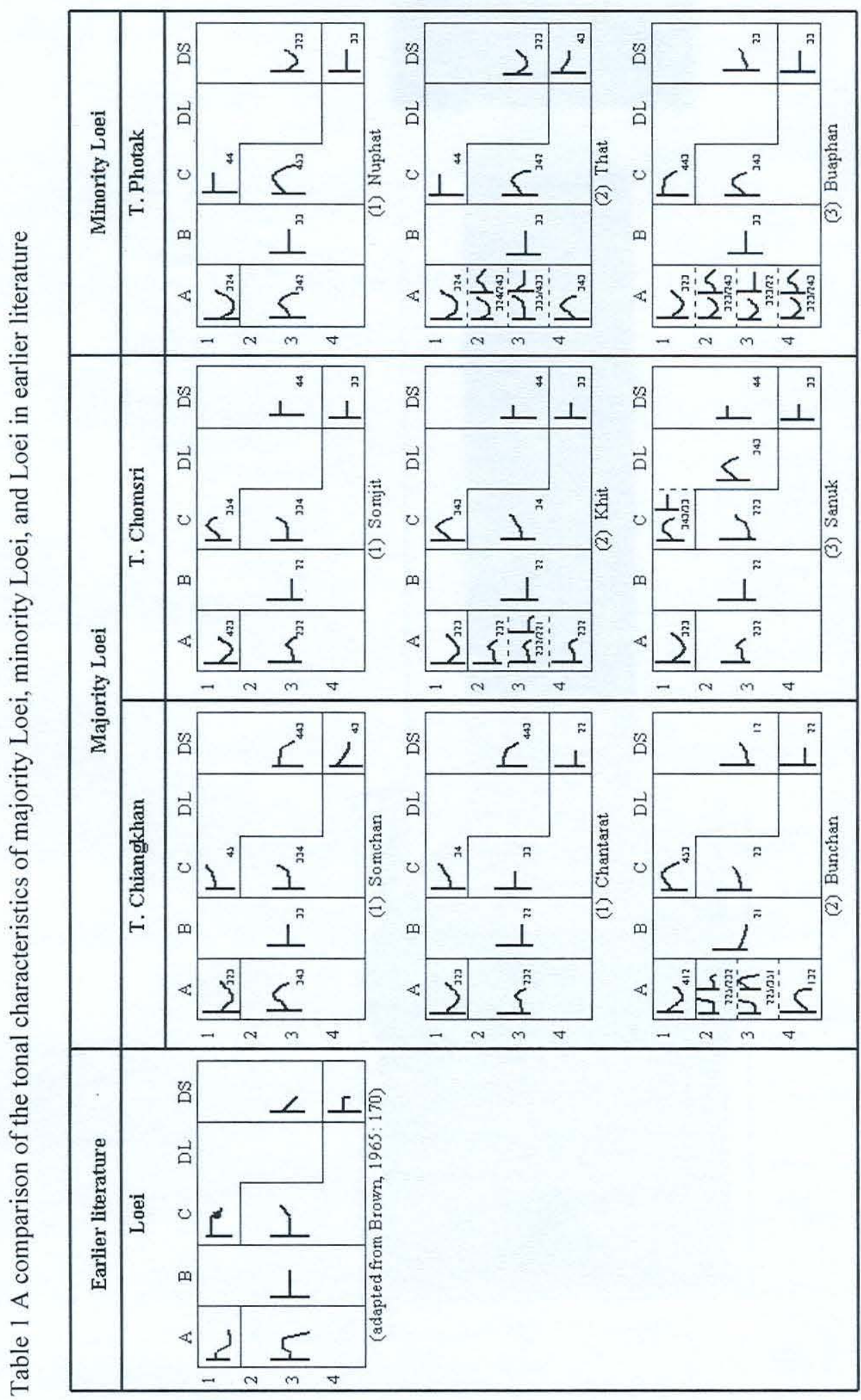




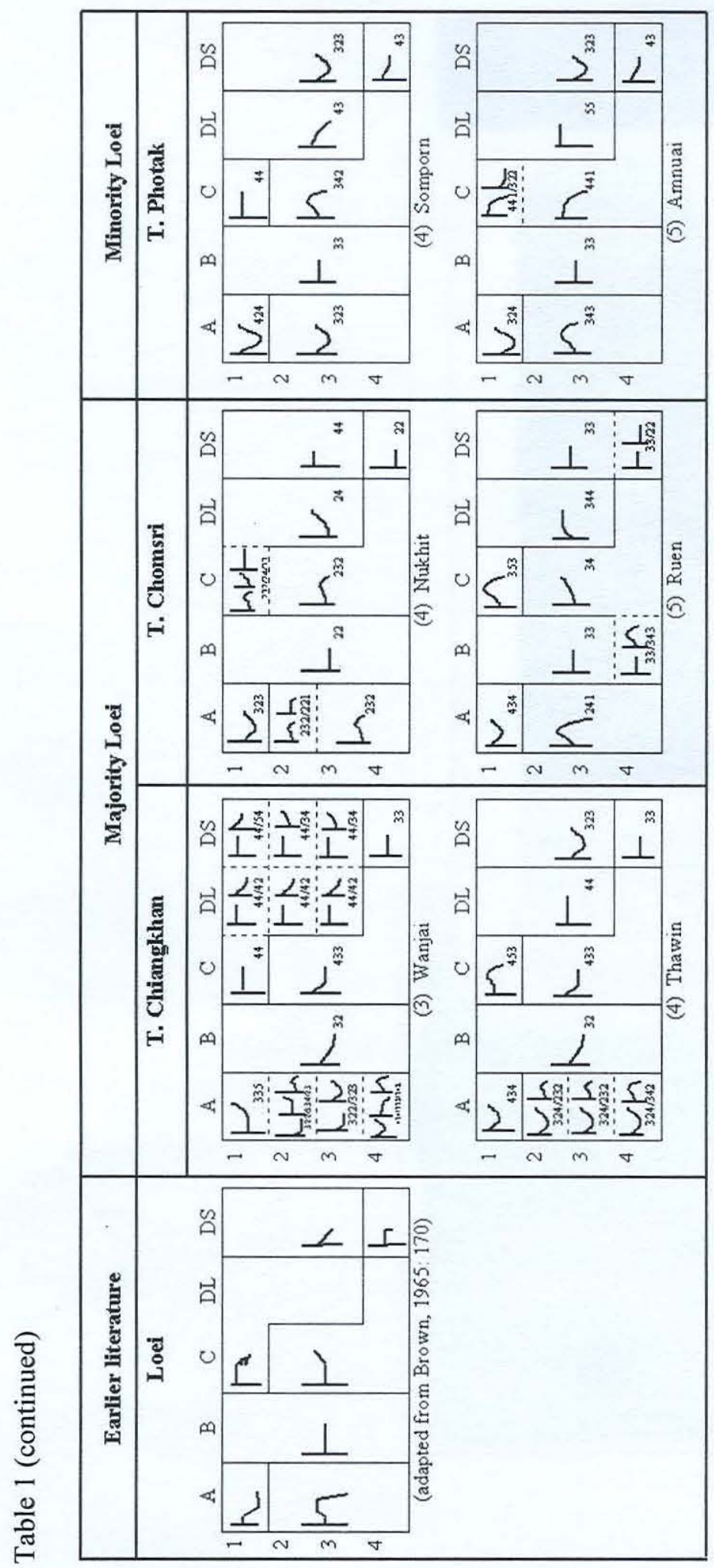


other provinces of Isan, e.g., Nong Khai, Kalasin, Chaiyaphum, and Khon Kaen) living in the same area, ${ }^{20}$ is a rising tone too. Given the available data in this study, it is therefore suspected that tone Al of majority Loei in T. Chiangkhan has been influenced by tone A1 of minority Lao Isan. It can be concluded that the change of tone $\mathrm{A} 1$ of majority Loei in T. Chiangkhan was induced by an external factor, language contact.

As for tones A234, only two speakers of majority Loei in T. Chiangkhan have no variation. The rising-falling tone of Somchan and Chantarat is as in Brown (1965), while that tone of the other three speakers shows variation. The variants of tones A234 of those three speakers are low-rising, rising(-falling), low-level, and fallingrising. These variants are suspected to have been influenced by both internal and external factors, e.g., the low-level and mid-level(-falling) tones of Wanjai are the same as in Lao Isan and Standard Thai. As for the rising tone, which is also a variant of tones A234, it is suspected to have been induced by an internal factor, simplification. In other words, it may be possible that the rising-falling tone which is more marked has been simplified to be less marked, i.e., a rising tone. Such a case of variation is also found in tones A234 of minority Lao Isan spoken in the same area (see Appendix 3).

As for tones $\mathrm{C} 1 / \mathrm{DL} 123$, in Brown (1965) such tones are high-levelfalling, but in the speech of majority Loei in T. Chiangkhan they are mostly found to be high-rising, high-risingfalling, high-level, and high-falling. It

\footnotetext{
${ }^{20}$ See tonal characteristics of minority Lao Isan in T. Chiangkhan in Appendix 3.
}

seems that the high-level-falling tone has been changed to high-rising, highrising-falling, high-level, or highfalling (see Conclusion and Discussion).

Tones DS123 of majority Loei in T. Chiangkhan are also completely different from Brown (1965), where they are low-level. In this study those tones of most of the majority Loei speakers appear as high-level, lowrising, high-falling, mid-rising, and falling-rising variants. All the rising variants of tones DS123 were probably borrowed from minority Lao Isan immigrants who have rising tones in DS123 also. But for the high-level tone, which is also a variant of tones DS123, it cannot be concluded where it is from. There is only the evidence that in the Paklaj (Sayyaburi) speech of Phaeng, a Lao immigrant from the Lao PDR, spoken in the same area, tones DS123 are also high-level (see Table 2). In fact, more data related to this issue are needed to conclude whether or not tones DS123 of majority Loei in T. Chiangkhan have been influenced by tones DS123 of minority Paklaj (Sayyaburi).

\subsubsection{Majority Lao Loei in $\mathrm{T}$. Chomsri}

An examination of the varieties of majority Loei in T. Chomsri reveals that some tones are highly varied and some are not. Tone Al is fallingrising, similar to tone $\mathrm{Al}$ of Loei in Brown (1965). The variation found in tones A234 of majority Loei in T. Chomsri is similar to that of $\mathrm{T}$. Chiangkhan but less so. A risingfalling tone is found mostly in tones A23 and A4 in the speech of every majority Loei speaker in this area, but there is also another variant of tones A234, a low-level tone, which also comes from 
the influence of minority Lao Isan. There is also variation in tone B4, the effect of an external factor. Normally B4 of Loei is assumed to be mid-level but for speaker Ruen of majority Loei in this group, the words in B4 are pronounced with mid-level and risingfalling contours. Such a rising-falling tone results from the interference of Standard Thai, which has a falling tone in B4.

As for tones $\mathrm{C} 1 / \mathrm{DL} 123$, the risingfalling tone in C1/D123 still remains in the speech of most speakers in this area. By the way, the variation of such a tone is also clearly seen in the speech of some speakers; that is, in $\mathrm{Cl}$ of Sanuk and Nukhit a mid-level tone is found, while in $\mathrm{Cl}$ of Nukhit, a rising tone is also a variant. Both variants of tone $\mathrm{C} 1$, mid-level and rising tones, are thought to have been simplified from rising-falling tones. Tones DL123 in most of the speakers in this group are rising tone, which is different from Brown (1965). For one speaker, Ruen, it can be seen that DL123 is high-level, different from the other speakers' and Brown's. Since Ruen's tone in $\mathrm{Cl}$ is risingfalling and in DL123 high-level, there is a split between $\mathrm{C} 1$ and DL 123; in other words, there is no Lao ladder in the tonal system of Ruen. In the matter of the high-level tone in DS123 of T. Chomsri, it cannot be decided whether the tonal variation leading to it was caused by internal or external factors.

\subsubsection{Minority Lao Loei in $\mathrm{T}$. Photak}

One obvious change of tonal characteristics of minority Loei of $\mathrm{T}$. Photak in Nong Khai province is in tone $\mathrm{Al}$, which is a rising tone as in majority Loei for both $\mathrm{T}$. Chiangkhan and $\mathrm{T}$. Chomsri but is different from
Brown (1965). As in both aforementioned varieties of majority Loei, the variations are also found mostly in tones A234 which appear as rising-falling, rising, mid-level, or low-level in the speech of some minority Loei speakers. The rising tone is suspected to be a simplification of the rising-falling tone, which also appears in A234 of Loei in Brown (1965), while the mid-level tone (in A3 of That) and low-level tone (in A3 of Buaphan) are borrowed from Standard Thai and Lao Isan respectively, as the speakers are bidialectals, being able to speak Lao Loei and Standard Thai, along with the other Loei speakers in the same area, as well as in T. Chiangkhan and T. Chomsri.

Comparing the variations of C1/DL123 in minority Loei of $T$. Photak with majority Loei in $\mathrm{T}$. Chiangkhan and T. Chomsri in Loei province, we can say that minority Loei speakers of T. Photak still keep the same tone of Loei, i.e., high-level or high-level-falling, which is more consistently the same as tones C1/DL123 of Loei in Brown (1965). As can be seen in Table 1, for tone C1 most of the minority Loei speakers have high-level or high-level-falling tones, while only one speaker (Amnuai) shows variation; this speaker's switching between a highlevel-falling tone and low-level tone may have been borrowed from majority Lao (Vientiane accent), ${ }^{21}$

21 Lao (Vientiane accent) is spoken by majority group in T. Photak, Photak subdistrict, Nong Khai Province. According to information from the informants of this group and from other people in this area, the ancestors of this majority people migrated from Vientiane, Lao PDR. This group of people identify 
spoken in the same area. By the way, when considering tones $\mathrm{C} 1 / \mathrm{DL} 123$ of Lao (Vientiane accent), the majority of T. Photak (see Appendix 3), we notice that all of tonal patterns of Lao (Vientiane accent) have falling tone - mid-falling, mid-level-falling, and high-falling - - not significantly different from the tones found in minority Loei. Therefore, it cannot be concluded that minority Loei borrowed the low-level tone of C1/DL123 from Lao (Vientiane accent), because not all the majority Lao (Vientiane accent) speakers have low-level tones in it. Accordingly, it is plausible that such tones of majority Lao (Vientiane accent) were influenced by minority Loei spoken in the same area, since the tones in C1/DL123 of majority Lao (Vientiane accent) are expected to be low tones as in Lao Isan (Vientiane accent) ${ }^{22}$ spoken in nearby provinces, e.g., Udonthani, Khon Kaen, and Kalasin (see Appendix 3).

One more obvious indication that

themselves as "Lao" and their dialect as /laaw sămnian wiantçan/ "Lao (Vientiane accent)" in order to separate themselves from "Vientiane Lao" in Lao PDR or "Lao Isan", a majority group of the Isan region.

${ }^{22}$ In Brown (1965) the Lao language is divided into three subgroups: Luang Prabang, Vientiane, and Nyo. Vientiane seems to be the largest group, composed of more dialects than the others. In the Isan region of Thailand, Lao dialects of the Vientiane group are widely spoken in many provinces; Chaiyaphum, Nong Khai, Khon Kaen, Udonthatni, Kalasin, Roi-et, etc., while the dialects of Luang Prabang group are spoken in Loei province. Here it can be said that in the Isan region, the Lao dialects spoken with a Vientiane accent are more widely distributed than the Lao dialects spoken with a Luang Prabang accent. there is tone change in minority Loei of T. Photak is the rising-falling contour of the high-level-falling tone of C234/DL4, which is expected to be mid-level-rising as in Brown (1965). Such a falling tone is the same as what is found in majority Loei for only one speaker, Nukhit, in T. Chomsri. The rising-falling or high-level-falling tone found in C234/DL4 of minority Loei is considered to have been influenced by majority Lao (Vientiane accent) in which all of the speakers consistently have a high-level-falling or risingfalling tone. Thus it can be said that the change of mid-level-rising tone to falling tone as found in the minority Loei dialect of T. Photak is induced by language contact, an external factor. Externally influenced tone change in minority Loei is also found in tones DS123 in speakers in T. Photak, who have a rising tone, as in majority Lao (Vientiane accent). Such tones are different from majority Loei in $\mathrm{T}$. Chomsri in which tones DS123 of all speakers are high-level, while in majority Loei of T. Chiangkhan, some speakers have a rising tone and some have a high-level tone. Comparing the tones DS123 of majority Loei and minority Loei in the studied area with Brown (1965), we can say that the low-level tone of Loei (Brown, 1965 ) is not maintained any more in the three groups of Loei in this study.

\subsubsection{Minority Lao immigrants from Lao PDR}

The variations and changes of tonal characteristics found in minority Lao immigrants from the Lao PDR. in T. Chiangkhan and T. Chomsri are shown in Table 2.

As can be seen in Table 2, only a speaker of Paklaj (Sayyaburi) in 


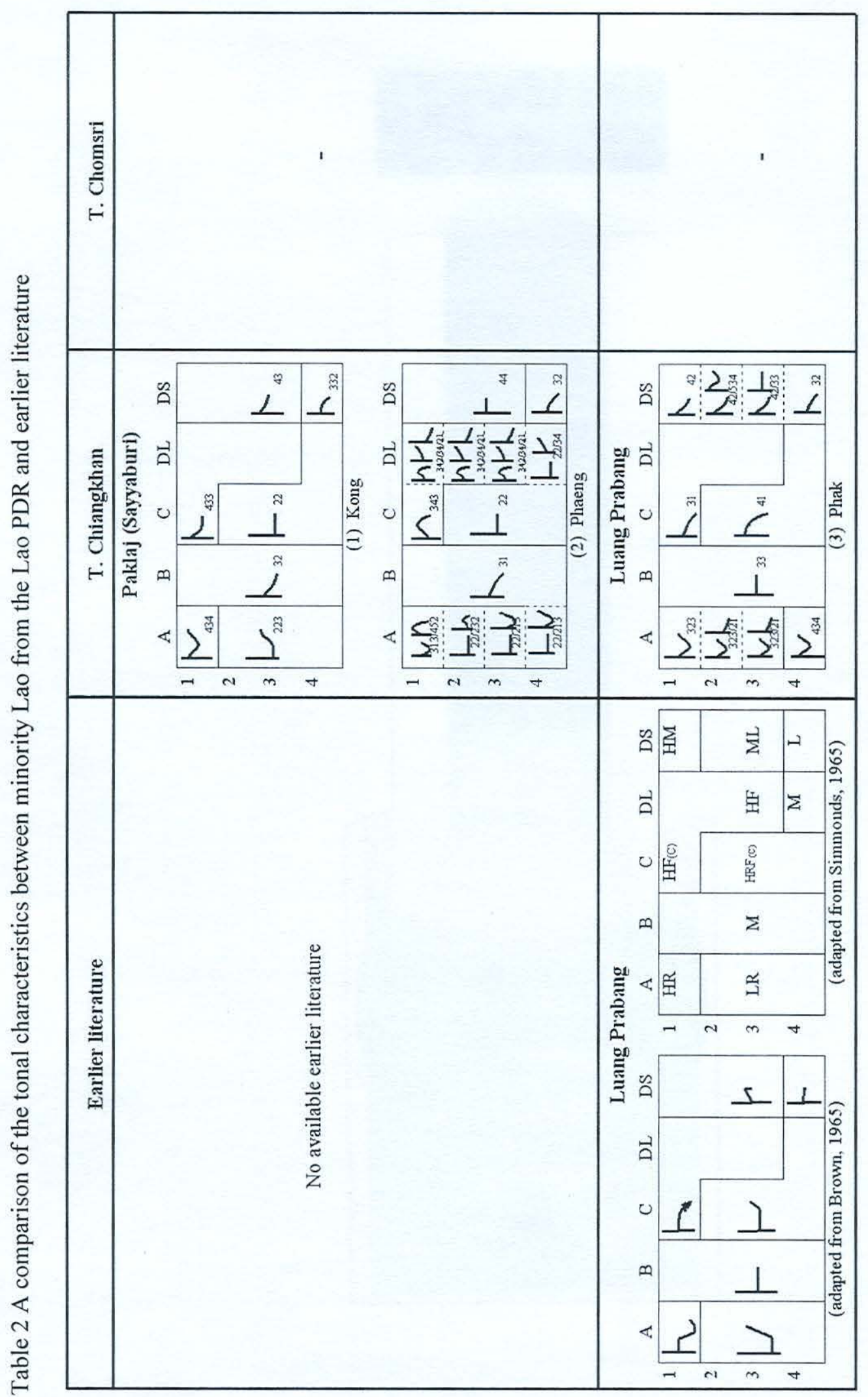




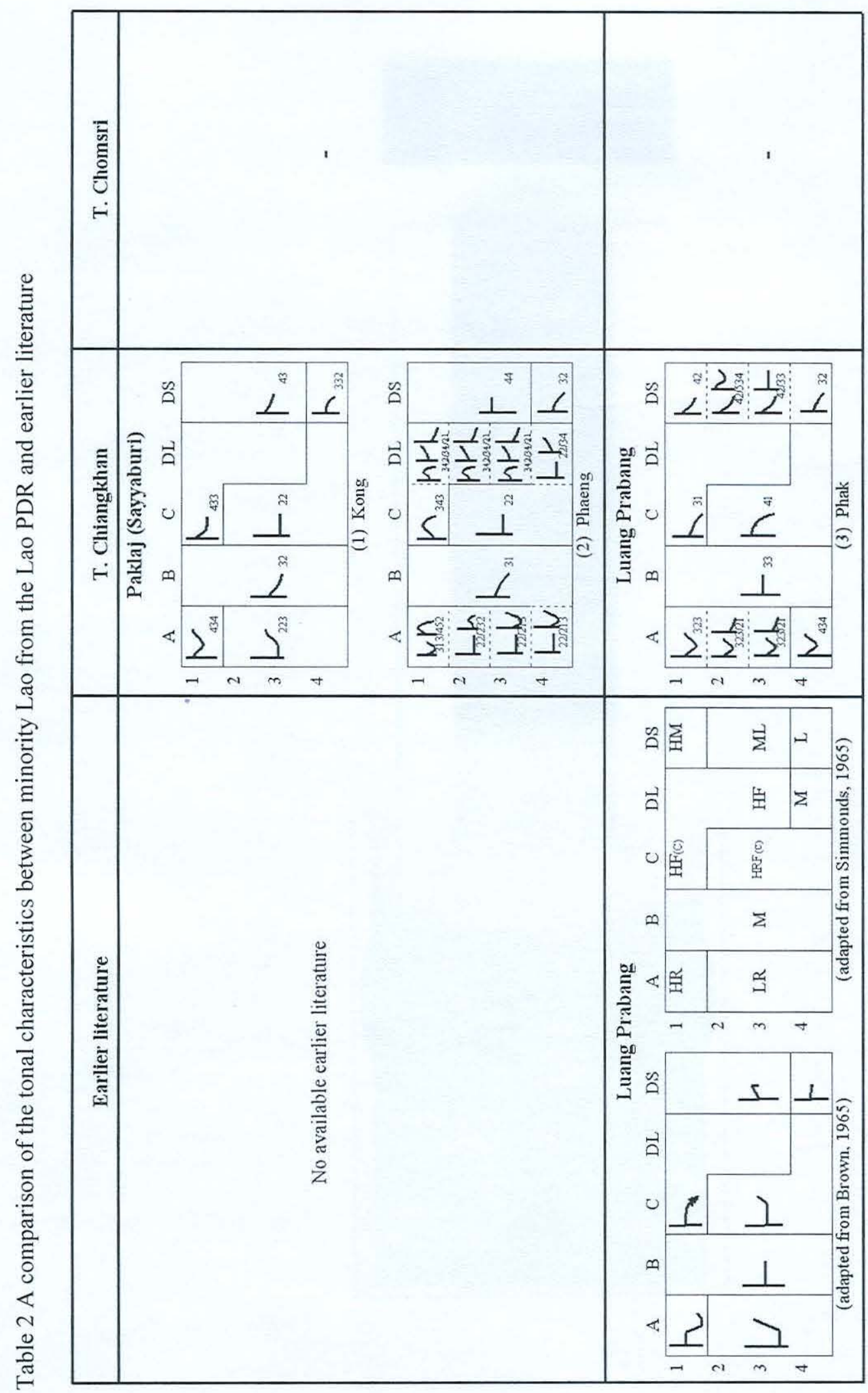


Tonal Variation and Change in Dialects in Contact: A Case Study of Lao

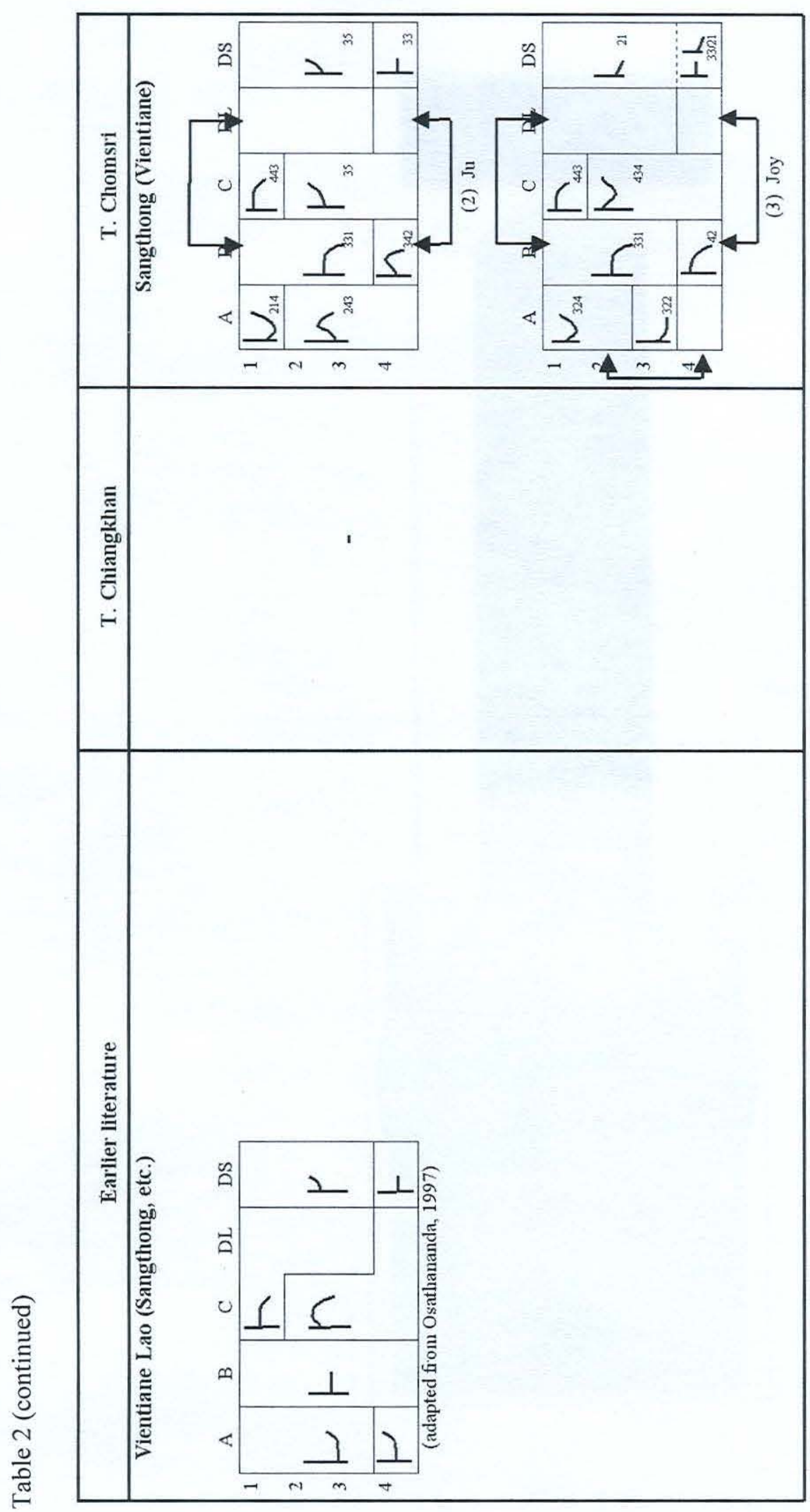


T. Chiangkhan and a speaker of Sanakham (Vientiane) in T. Chomsri have clear patterns of tonal mergers and splits, which means that they pronounce each tone consistently. By the way it cannot be concluded that there is no change in the minority Lao language of such speakers, since in comparison with majority Loei spoken in the same area, it is found that some tones in the minority Lao language are similar to the ones in majority Loei.

As for Paklaj (Sayyaburi) in $\mathrm{T}$. Chiangkhan, it can be seen from Table 2 that the tones of the second speaker (Phaeng) are highly varied, while those of the first speaker (Kong) are few in number, especially tones C1/DL123. In the minority Lao of Phaeng the variations are found in tone $\mathrm{A}$; that is, A1 switches between rising and rising-falling tones, differing from Kong, who has only a falling-rising tone in $\mathrm{Al}$, like $\mathrm{Al}$ in most majority Loei speakers in the same area. Moreover, tones A234 of Phaeng also vary between low-level, rising-falling, and falling-rising tones, and it is suspected that the low-level tone is borrowed from Standard Thai, which Phaeng also speaks. Since there is no literature available on Lao Sayyaburi, it cannot be concluded whether or not there is change in Paklaj (Sayyaburi) in T. Chiangkhan.

As for Luang Prabang, variations are found in tones A23 and DS23. Tones A23 of the Luang Prabang speaker in this study switch between fallingrising and low-falling tones, which, I think, have been borrowed from Lao Isan, since in most varities of Lao Isan A23 are low-falling tones. As for the variations in tones DS23, it is suspected that the rising tone in DS2 has also been borrowed from Lao Isan. Compared with Luang Prabang in
Brown (1965) and Simmonds (1965), it can be seen that most of the tonal characteristics of Luang Prabang in this study are similar to Brown, while some tones are different from Simmonds, especially tone DL4 (see Table 2).

In the case of Sanakham (Vientiane), it can be seen in Table 2 that there is a great variety of tonal characteristics in both speakers (Chanto and Pan are husband and wife), especially tones $\mathrm{A} 1$ and $\mathrm{C} 1234$ of Pan and A1234 of Chanto. In the light of the treatment of the tones of Sanakham (Vientiane) in Osathananda (1997) and of Vientiane in Simmonds (1965) and Brown (1965), tone Al is expected to be rising, but both speakers of Sanakham (Vientiane) in this study switch between a rising tone and $\mathrm{mid} / \mathrm{low}-$ level tone. Such variation is suspected to be a case of the simplification from rising tone to level tone, similar to the variations of some tones in majority Loei and minority Loei. Tones A234 of Pan are rising-falling, different from the aforementioned available literature, while in the Sanakham (Vientiane) of Chanto, such tones switch between low-falling, risingfalling, and rising tones. The variations in tones $\mathrm{C} 1234$ of Pan are thought to have been influenced by Standard Thai (hign(-level)-falling tone in C1234) and Lao Isan (midfalling in $\mathrm{C} 1$ ). Even though both speakers are a couple, living together, their tonal variations differ somewhat and it is noticed that tone $\mathrm{Cl}$ of Chanto is rising, different from the earlier literature, while tones DL123 are falling, the same as Sanakham (Vientiane) in Osathananda (1997). Thus it can be seen that tone $\mathrm{Cl}$ of Chanto obviously splits from tones DL123. From the evidence in this study, it can tentatively be concluded 
that tone A, especially A234 in minority Sanakham (Vientiane) of both speakers, may have been influenced by the majority Loei spoken in the same area.

With regard to minority Sanakham (Vientiane) in T. Chomsri, it can be said that tone A23 of the speaker (Niphon) is rising-falling, the same as in majority Loei spoken in the same area but different from the earlier literature. It can also be seen that most of the tones are still maintained in the minority Sanakham (Vientiane) of this speaker, especially the rising tone in $\mathrm{A} 1$, level tone in B1234, mid-falling tone in $\mathrm{C} 1 / \mathrm{DL} 123$, rising tone in DS123, and level tone in DS4. As for the minority Sangthong (Vientiane) spoken in the same area, it is suspected that both speakers are "Phuan" as mentioned in section 1, but some of their tonal characteristics have been influenced by majority Loei, for example, falling-rising in A234 $(\mathrm{Ju})$, rising in $\mathrm{C} 234$ (Ju and Joy), and mid-level tone in DS4 (Ju). Therefore, it can be tentatively concluded that the tones of both Sangthong (Vientiane) speakers are a mixture of Phuan and Loei.

\section{Conclusion and Discussion}

On the basis of the tone data of majority Loei, minority Loei, and minority Lao immigrants from the Lao PDR, the overall patterns of tonal mergers and splits for Loei, a dialect of Lao Isan, and Lao dialects of Lao immigrants from the Lao PDR, can be summarized as shown in Figure 5.

As can be seen from Figure 5, the "Lao Ladder" (C1=DL123/C234=DL4), a distinctive pattern of the Lao language, is maintained in the overall patterns of tonal mergers and splits of Loei,
Paklaj (Sayyaburi), Luang Prabang and Sanakham (Vientiane). The distinctive pattern of Tone A, A1-234 , is changed to A1-234 in Loei as well as Paklaj (Sayyaburi), while the mergers and splits pattern of Tone A in the other Lao dialects: Luang Prabang and Sanakham Vientiane, is found to have been changed to A1-234(?) and perhaps A1-23-4(?) respectively. The tonal variations and changes found in these Lao dialects lead to the conclusion that the overall patterns as shown in Figure 5 are maintained only in the Lao dialects of some speakers.

The variations and changes in each tone of majority Loei, spoken in $\mathrm{T}$. Chiangkhan and T. Chomsri, Chiangkhan district, Loei province, and minority Loei in T. Photak, Photak subdistrict, Nong Khai province, are shown in Figure 6.

Even though the distinctive tonal patterns of the Lao language are preserved in the Loei of some speakers, both in majority and minority Loei as can be seen in Figure 6 (see also Figure 2 and Figure 3), it can be noticed that pattern $\mathrm{Cl}=\mathrm{DL} 123$, one of the distinctive patterns, is not maintained in the Loei of some speakers, not only in minority but also in majority Loei (see Tonal pattern (4) of Loei in T. Chiangkhan, Tonal pattern (5) of Loei in $T$. Chomsri, and Tonal pattern (4)\&(5) of Loei in T. Photak in Figure 3.) Given the similarity between the patterns of tonal mergers and splits and the tonal characteristics of majority Loei, minority Loei, and minority Lao immigrants in comparison with the available literature and the distinctive tonal patterns of the Lao language proposed in this study, it can be concluded that variation and change can occur not only in dialects of the 
Figure 5 The overall patterns of tonal mergers and splits of Loei, Paklaj (Sayyaburi), Luang Prabang, and Sanakham (Vientiane)

Loei
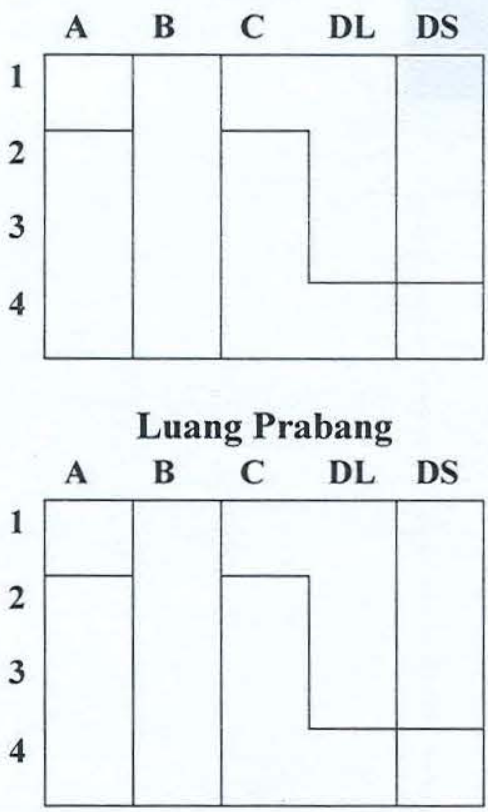

minority, but also of the majority. In addition, it can be said that such variation and change can take place to the same degree. That is, it is not necessarily such that in dialects in contact situations, the dialects of the minority are influenced to a higher degree than the dialects of the majority.

One of the social predictors of contact-induced change is the numbers count which can help predict the change, i.e., if one of two groups in contact is much larger than the other, the smaller group's language is more likely to acquire features of the larger group's language than if the two groups are roughly equal in size. In part this is due to the fact that a larger culture is likely to be a dominant culture: the more socioeconomic dominance one of the groups exerts, the more likely it is that the subordinate group will adopt features from the dominant group's language. The social reasons are complex, but
Paklaj (Sayyaburi)

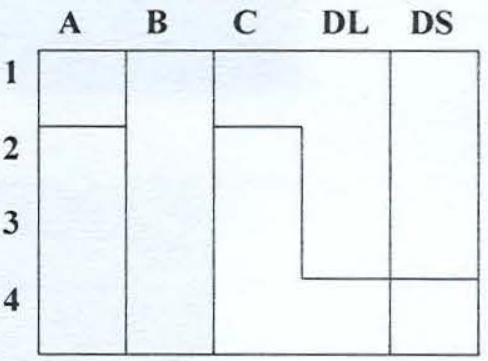

Sanakham (Vientiane)

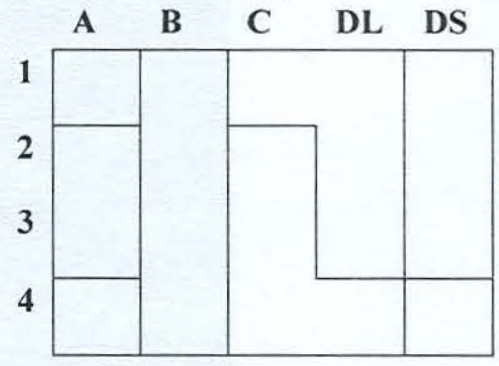

one obvious point is that members of the subordinate group are likely to become bilingual and, again, this makes extensive interference possible. (Thomason, 2001: 66) As for the case that some tones in majority Loei are influenced by minority Lao Isan dialects (Nong Khai, Khon Kaen, Kalasin, Chaiyaphum, and Nongbualumphu) which are all in the Vientiane group, can be taken as evidence that the majority dialect/language may not be dominant in every case. In the Isan region, the Lao dialects in the Vientiane group are spoken more widely than the Lao dialects in Luang Prabang. Therefore, it can be said that the dominant group in the Isan region is Lao in the Vientiane group. This may be the reason why majority Loei dialects (Luang Prabang group) are influenced by minority Lao Isan.

The interference between majority and minority tones found in this study can 
Figure 6 The variations and changes of each tone in majority Loei and minority Loei ${ }^{23}$

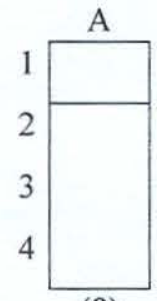

(8)

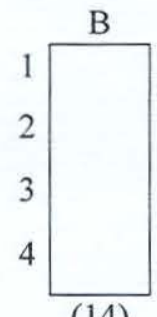

(14)

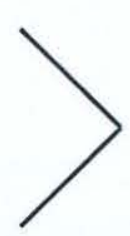

(1)

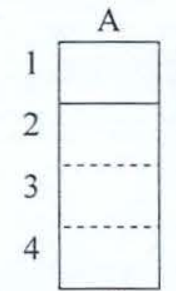

(3)

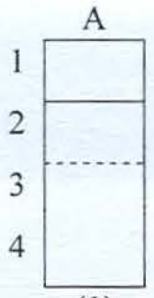

(1)

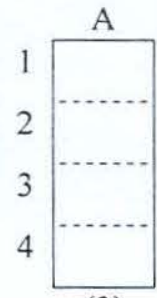

(3)

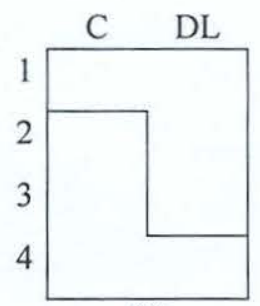

(8)
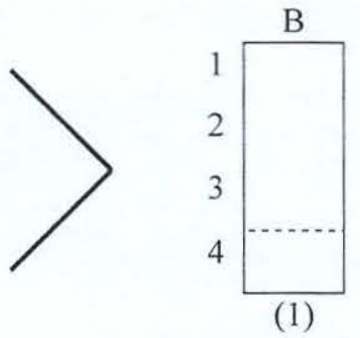

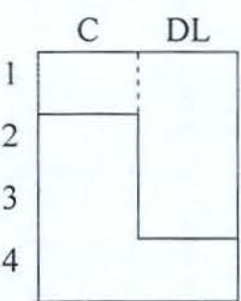

(1)

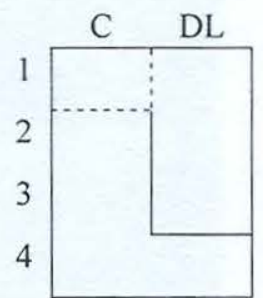

(1)

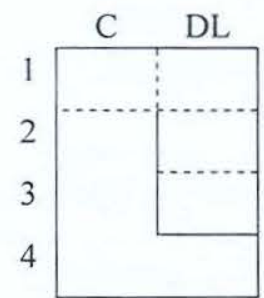

(1)

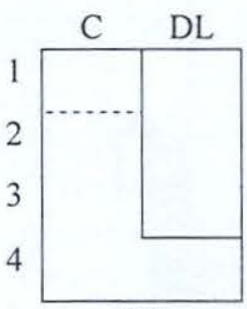

(1)

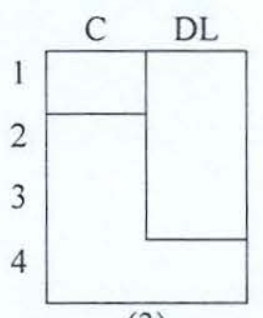

(3)

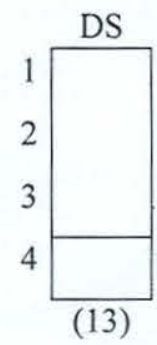

create a new mixed pattern. Pronunciation borrowing is a

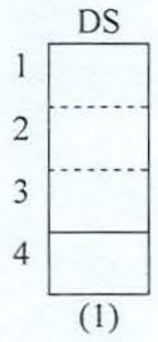

phenomenon that occurs in a situation of dialects in contact. In other words,

\footnotetext{
${ }^{23}$ The number in a bracket below a column of each tone represents the number of speakers whose Lao dialects have each pattern of tonal variation and change.
} 
when two or more groups of people speaking different dialects live in the same area, they certainly cannot avoid communicating with each other by using each other's words. The pronunciation will then be imitated automatically.

The variations and changes induced by an internal factor found in this study are suspected to have been caused by simplification from more marked tones to less marked tones. The steps of the simplification can be tentatively sketched as in Figure 7. The variations and changes of the tones shown affect the patterns of tonal mergers and splits as described in section 3 .

Confusion between ethnic names and tonal systems is also found in this study. Thus, two Lao immigrants from the Lao PDR living in T. Chomsri identified themselves as "Lao" but their patterns of tonal mergers and splits are apparently Phuan, because their patterns are the same as the tonal patterns of Phuan shown in Figure 8.

As can be seen in Figure 8, the tonal patterns of the first speaker $(\mathrm{Ju})$ are the same as the patterns of Phuan, spoken in Photak district, Nongkhai province and similar to Phuan, spoken in Lopburi and Suphanburi provinces (especially the $\mathrm{B}=\mathrm{DL}$ patterns), while Lao Sangthong of the second speaker (Joy) also shows patterns of tonal mergers and splits similar to the aforementioned patterns of Phuan. According to the main patterns of tonal mergers and splits $(B=D L)$, it can be said that both speakers from Muang Sangthong in Vientiane, who migrated to Chomsri subdistrict, are not "Lao" as self-identified but rather Phuan.

Figure 9 indicates that some tones of both Sangthong (Vientiane) speakers are similar to the tones of Phuan in the earlier literature. The tonal characteristics of both speakers are similar to Phuan in Suphanburi and Singburi provinces (in Thailand), especially the rising tone in $\mathrm{Al}$, risingfalling or falling tone in B4 and DL4, high-level-falling tone in $\mathrm{Cl}$ (similar to high-level of Phuan in Tanyong, 1983). This similarity can be taken as evidence to support the argument that both speakers of Sangthong (Vientiane) may be Phuan-speakers, although some of their tones were influenced by Loei, spoken as the majority dialect in the same area. Thus, they have a mixture of Phuan and Loei tones. More data are needed for an exact conclusion about this issue.

One more piece of evidence supporting this tentative conclusion is from my personal communication with a Laotian from the Lao PDR whom I met by chance. On being questioned about Phuan in Sangthong of the Lao PDR, he told me that there are scattered Phuan living in Sangthong. For him, there is no suspicion that those two immigrants in T. Chomsri who identified themselves as Lao are in fact Phuan. Such a case of ethnic-name confusion is like the case of the "Nyo" people living in the same area of Lao Isan and Phuthai in the northern part of That Phanom district, Nakhon Phanom province in northeastern Thailand, whose ethnic name is not in agreement with their linguistic characteristics. Such ethnicname confusion is probably caused by variations or changes in dialects and languages (Akharawatthanakun, 2002). From this evidence, it can be concluded that the confusion of ethnic names can occur in a situation of dialects and languages in contact. 
Figure 7 The simplification of tones found in the studied majority and minority dialects

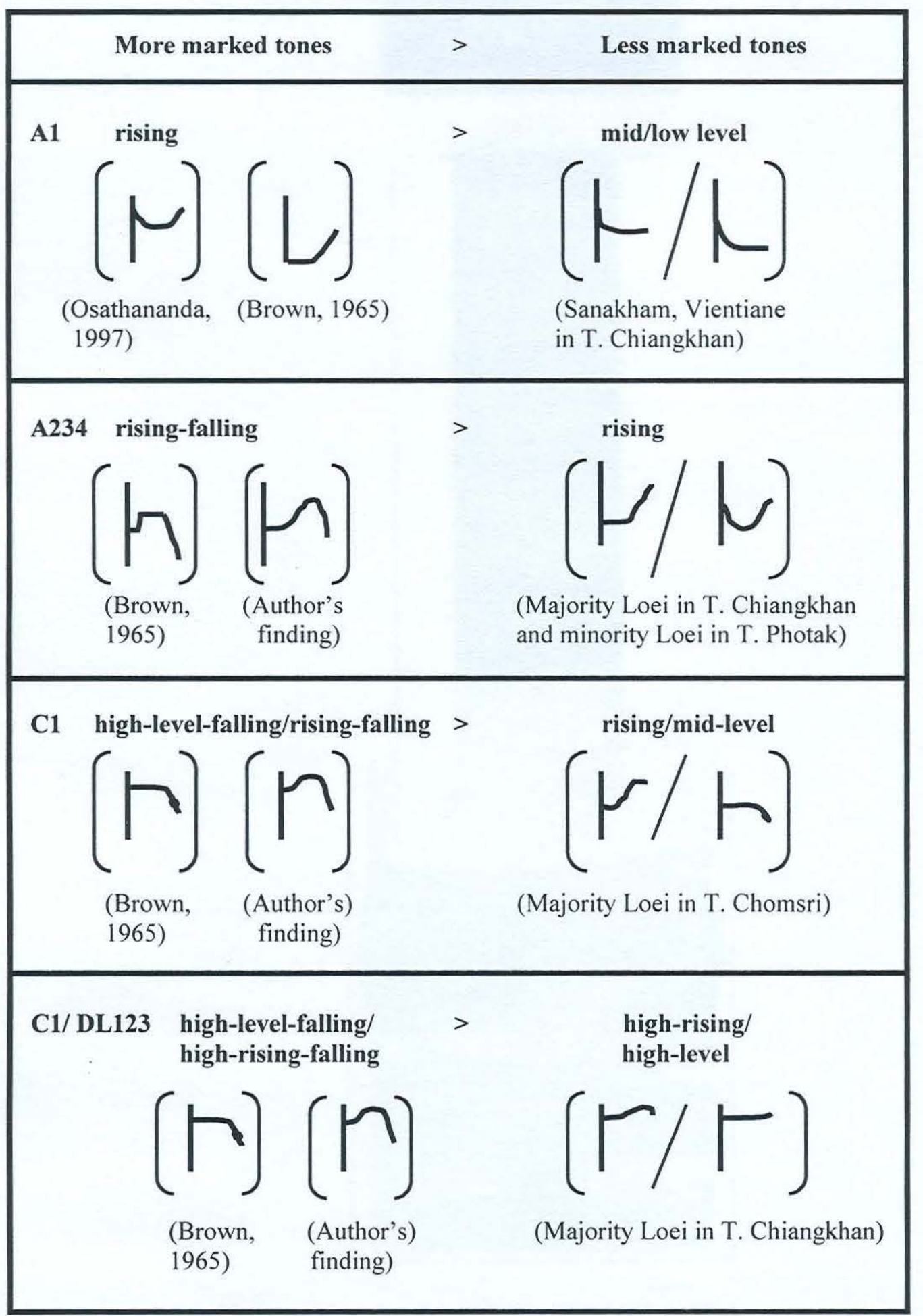


Figure 8 Comparison between the patterns of tonal mergers and splits of Lao Sangthong (Vientiane) and Phuan

\begin{tabular}{|l|l|}
\hline Sangthong, Vientiane & Spoken in Photak district, Nong Khai \\
province 24 \\
province in Chomsri subdistrict, Loei
\end{tabular}

${ }^{24}$ From this same research of the author. 
Figure 9 A comparison of tones in Sangthong (Vientiane) and Phuan

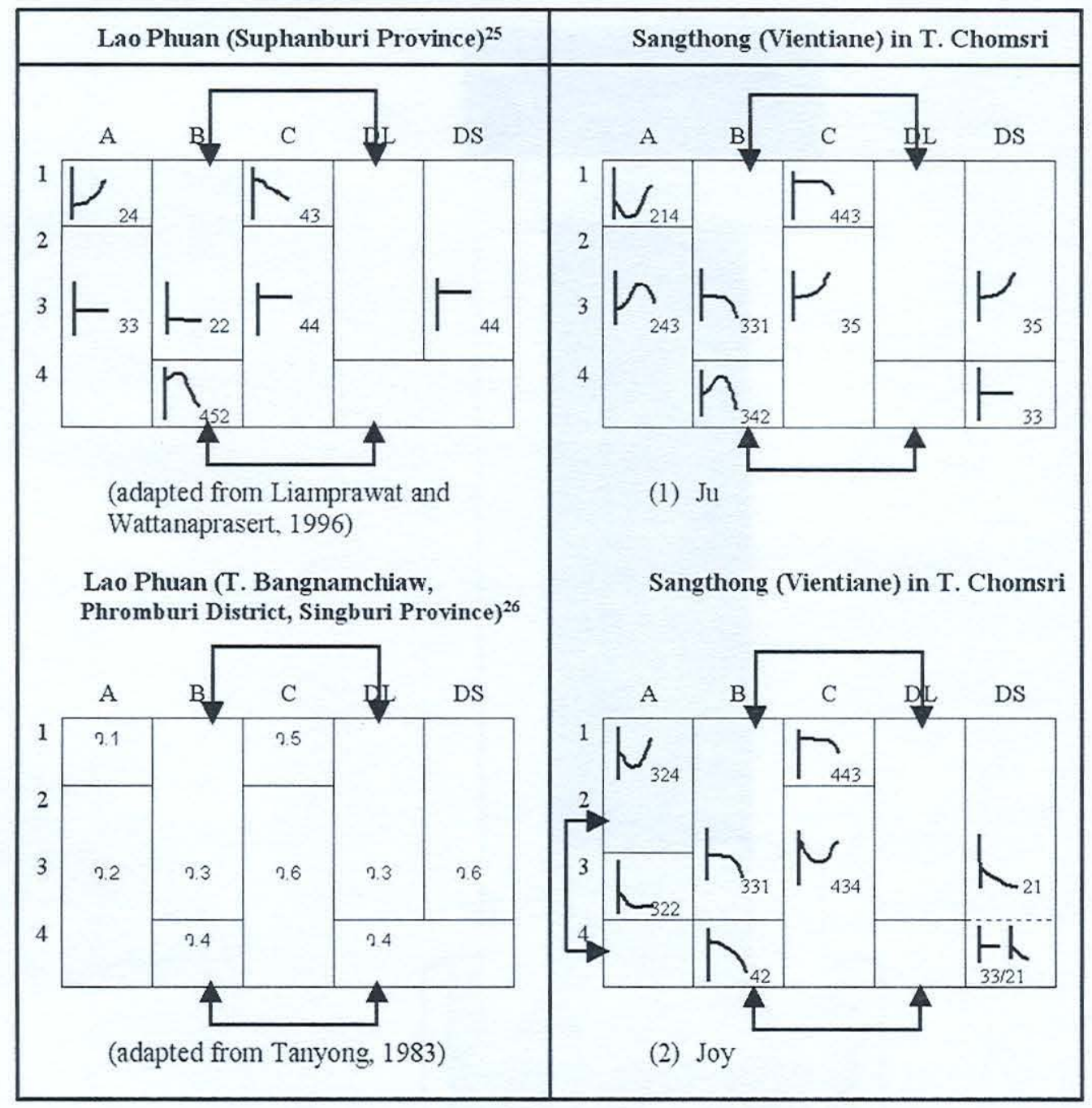

${ }^{25}$ In this source, "Lao Phuan" is used while "Phuan" is used in this paper.

${ }^{26}$ Only the pattern of tonal mergers and splits is provided in this source. 


\section{References}

Akharawatthanakun, Phinnarat. 1998.

A Comparative Study of the

Tonal System in the Speech of

the "Lao", the "Nyo" and the

"Phuthai" in That Phanom

District, Nakhon Phanom

Province. Unpublished M.A.

thesis, Department of

Linguistics, Chulalongkorn

University. (in Thai)

Akharawatthanakun, Phinnarat. 2002.

Tonal variations and changes in a language mixture area: A case study of northeastern Thailand (Isan). MANUSYA 5: 30-51.

Brown, J. Marvin. 1965. From Ancient Thai to Modern Dialects. Bangkok: Social Science Association Press.

Chantanakom, Wanna and Rattanaprasert, Wanna. 1983. Lao Viang at Nong Nae. Borannakhadi 26. Bangkok: Silpakorn University, pp. 234241. (in Thai)

Chinchest, Pornsri. 1989. Lao Ngaew Tones in Citation Forms and in Connected Speech. Unpublished M.A. thesis, Department of Linguistics, Chulalongkorn University. (in Thai)

Clyne, Michael. 1975. Forschungsbericht Sprachkontakt. Kronberg: Seriptor. Cited in Salmons, Joe. 1992. Accentual Change and Language Contact: Comparative Survey and a Case Study of Early Northern Europe. Stanford, California: Stanford University Press.

Daecha, Wilailuck. 1987. A Comparative Study of the

Phonology of Six Tai Dialects Spoken in Amphoe Tha Tako, Changwat Nakhon Sawan. Unpublished M.A. thesis, Department of Linguistics, Chulalongkorn University. (in Thai)

Dejvongsa, Sulang et al. (eds.) 1972. Khonkhwaa Phaasaa Lao. (Lao Language Research)

Gedney, William J. 1972. A checklist for determining tones in Tai dialects. In M. Estellie Smith (ed.). Studies in Linguistics in Honor of George L. Trager. The Hague: Mouton, 423-437.

Haas, Mary. 1958. The tones of four Thai dialects. Reprinted from The Bulletin of the Institute of History and Philology. Academia Sinica Vol. XXIX. Studies Presented to Yuen Ren Chao on his Sixty-fifth Birthday. Taipei, Taiwan, China, pp. 817-826.

Hoonchamlong, Yuphaphan. 1985.

Tones in Pakse Lao: A preliminary analysis. (Mimeographed)

Khanittanan, Wilaiwan Wichienrot. 1973. The Influence of Siamese on Five Lao Dialects. Unpublished doctoral dissertation, University of Michigan.

Li, Fang Kuei. 1977. A Handbook of Comparative Tai. Honolulu, Hawaii: University Press of Hawaii.

Liamprawat, Suwattana and Wattanaprasert, Kantima. 1996. An Analysis of Lexical Use and Variation among Three Generations in Lao Language 
Communities of Thacin River

Basin. Nakhon Pathom: The

Institute of Research and

Development, Silpakorn

University. (in Thai)

Martinet, A. 1952. Function, structure, and sound change. Word 8, 1-32. Cited in McMahon, April M.S. 1994. Understanding Language Change. Cambridge: Cambridge University Press.

McMahon, April M.S. 1994. Understanding Language Change. Cambridge: Cambridge University Press.

Osatananda, Varisa. 1997. Tone in Vientiane Lao. Unpublished doctoral dissertation, University of Hawaii.

Panka, Kanchana. 1980. The Phonological Characteristics of Lao Dialects in Amphoe Muang, Nakhon Pathom. Unpublished M.A. thesis, Department of Linguistics, Chulalongkorn University. (in Thai)

Pungpaopan, Nongnut. 1984. The Characteristics of Lao Ngaew, Tambon Thong En, Inburi District, Singburi Province. Unpublished M.A. thesis, Silpakorn University. (in Thai)

Salmons, Joe. 1992. Accentual Change and Language Contact: Comparative Survey and a Case Study of Early Northern Europe. Stanford, California: Stanford University Press.

Simmonds, E.H.S. 1965. Notes on some Tai dialects of Laos and neighbouring regions. Lingua 14, 133-147.

Tanyong, Uthaiwan. 1983. An Analysis of Lexical Use among Three
Generations in Lao Phuan. Unpublished M.A. thesis, Silpakorn University. (in Thai)

Thomason, Sarah G. (ed.) 1997. Contact Languages: A Wider Perspective. Amsterdam: John Benjamins.

Thomason, Sarah G. 2001. Language Contact. Washington D.C.: Georgetown University Press.

Thomason, Sarah Grey and Kaufman, Terrence. 1988. Language Contact, Creolization, and Genetic Linguistics. Berkeley: University of California Press.

Trudgill, Peter. 1986. Dialects in Contact. New York: Basil Blackwell.

Ureland, P. Sture and Clarkson, Iain. (eds.) 1984. Scandinavian Language Contacts. Cambridge: Cambridge University Press.

Wattanaprasert, Kantima. and Liamprawat, Suwattana. 1985. The Phonology of Lao Dialects in Thacin River Basin. Department of Thai, Faculty of Arts, Silpakorn University. (in Thai)

Weinreich, Uriel. 1953. Languages in Contact: Findings and Problems. London: Mouton.

\section{Acknowledgement}

I would like to thank the Thailand Research Fund (TRF) for its financial support, and I am very grateful to Dr.Arthur S. Abramson and Dr.Theraphan L-Thongkum for their very helpful suggestions and comments. 


\section{Appendix 1 Test words}

\section{Set 1 Test words modified from Gedney's wordlist}

\begin{tabular}{|c|c|c|c|c|c|}
\hline & $\mathbf{A}$ & B & C & DL & DS \\
\hline 1 & $\begin{array}{l}\text { y [hŭu] 'ears' } \\
\text { ขา [khăa] 'legs' } \\
\text { หัว [hǔa] 'head' } \\
\text { สอง [š̌on] 'two' }\end{array}$ & $\begin{array}{l}\text { ไข่ [khày] 'egg' } \\
\text { ผ่า [phàa] 'to cut' } \\
\text { ช่า [khàa] 'ginger' } \\
\text { สั่ว [thùa] 'bean' }\end{array}$ & $\begin{array}{l}\text { ข้าว [khâaw] 'rice' } \\
\text { เสื้อ [sîa] 'shirt' } \\
\text { หม้อ [mồ] 'pot' } \\
\text { ห้า [hâa] 'five' }\end{array}$ & $\begin{array}{l}\text { ขวด [khùat 'bottle' } \\
\text { หมวก [mìk] 'hat' } \\
\text { ศอก [sjok] } \\
\text { 'elbows' } \\
\text { ลาก [sàak] 'pestle' }\end{array}$ & $\begin{array}{l}\text { หมัด [màt] 'flea' } \\
\text { ผัก [phàk] } \\
\text { 'vegetable' } \\
\text { หก [hòk] 'six' } \\
\text { ลิบ [sìp] 'ten' }\end{array}$ \\
\hline 2 & $\begin{array}{l}\text { ปู [pūu] 'crab' } \\
\text { ตา [tāa] 'eyes' } \\
\text { กิน [kin] 'to eat' } \\
\text { กา [kāa] 'crow' }\end{array}$ & $\begin{array}{l}\text { ไก่ [kày] 'chicken' } \\
\text { เป่า [pàw] 'to } \\
\text { blow' } \\
\text { เต่า [tàw] 'tuutle' } \\
\text { ปี [pì] 'flute' }\end{array}$ & $\begin{array}{l}\text { เก้า [kâaw] 'nine' } \\
\text { ป้อน [pôon] 'to } \\
\text { feed' } \\
\text { ก้าง [kîan] 'fish- } \\
\text { bone' } \\
\text { ตู้ [tûu] } \\
\text { 'wardrobe' }\end{array}$ & $\begin{array}{l}\text { ปีก [pùik] 'wing' } \\
\text { กอด [kj̀t] 'to hug' } \\
\text { ตอก [t.̀ok] 'to } \\
\text { hammer' } \\
\text { ปาn [pàak] } \\
\text { 'mouth' }\end{array}$ & $\begin{array}{l}\text { กบ [kòp] 'frog' } \\
\text { เจ็ด [cèt] 'seven' } \\
\text { เตะ [tè] 'to kick' } \\
\text { จับ [càp] 'to } \\
\text { touch' }\end{array}$ \\
\hline 3 & $\begin{array}{l}\text { บิน [bin] 'to fly' } \\
\text { แดง [dǣen] 'red' } \\
\text { บาน [bāan] 'to } \\
\text { blossom' } \\
\text { ดาว [dāaw] 'star' }\end{array}$ & 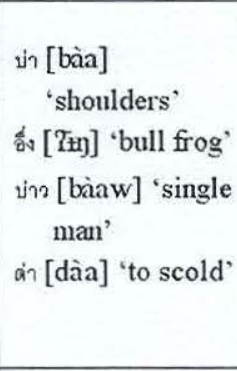 & $\begin{array}{l}\text { ด้าย [dâay] } \\
\text { 'thread' } \\
\text { จ้อย [?วิoy] 'sugar } \\
\text { cane' } \\
\text { ด้าม [dâam] } \\
\text { 'handle' } \\
\text { อ้า [?âa] 'to open } \\
\text { mouth' }\end{array}$ & $\begin{array}{l}\text { แดต [dæ̀æt] } \\
\text { 'sumshine' } \\
\text { บีบ [bìp] 'to } \\
\text { squeeze' } \\
\text { บอด [bòst] 'to be } \\
\text { blind' } \\
\text { ตีด [diit] 'to flick' }\end{array}$ & $\begin{array}{l}\text { เบ็ด [bèt] 'fish } \\
\text { hook' } \\
\text { ดิ [dip] 'to be } \\
\text { raw' } \\
\text { อก [?òk] 'chest' } \\
\text { เด็ด [dèt] 'to pick' }\end{array}$ \\
\hline 4 & $\begin{array}{l}\text { มือ [mīit] 'hands' } \\
\text { ดวาย [khwāay] } \\
\text { 'buffalo' } \\
\text { นา [nāa] 'rice } \\
\text { field' } \\
\text { ง [nūu] 'snake' }\end{array}$ & $\begin{array}{l}\text { พ่อ [ph5̂ว] 'father' } \\
\text { ว่าว [wâaw] 'kite' } \\
\text { เลื่อย [lıay] 'saw' } \\
\text { ม่าย [mâay] } \\
\text { 'widow' }\end{array}$ & $\begin{array}{l}\text { น้า [náa] 'aunt' } \\
\text { คิ้ว [khíw] } \\
\text { 'eyebrows' } \\
\text { น้ำ [náam] 'water' } \\
\text { ลิ้น [lin] 'tongue' }\end{array}$ & $\begin{array}{l}\text { มีด [mîit] 'knife' } \\
\text { เลือด [lîat] 'blood' } \\
\text { เขือก [chîak] 'rope' } \\
\text { มอด [m.jot] } \\
\text { 'woodmite' }\end{array}$ & $\begin{array}{l}\text { นก [nók] 'bird' } \\
\text { มด [mót] 'ant' } \\
\text { คร [klurók] } \\
\text { 'mortar' } \\
\text { เล็บ [lép] 'nail' }\end{array}$ \\
\hline
\end{tabular}




\section{Appendix 1 (Continued)}

Set 2 The analogous set

\begin{tabular}{|c|c|c|c|c|c|}
\hline & $\mathbf{A}$ & B & $\mathrm{C}$ & $\mathrm{DL}$ & DS \\
\hline 1 & $\begin{array}{c}\text { ขา [khǎa] } \\
\text { 'legs' }\end{array}$ & $\begin{array}{l}\text { ข่า [khàa] } \\
\text { 'ginger' }\end{array}$ & $\begin{array}{l}\text { ข้าว [khâaw] } \\
\text { 'rice' }\end{array}$ & $\begin{array}{l}\text { ขาด [khàat] } \\
\text { 'to be torn', }\end{array}$ & $\begin{array}{l}\text { ขัด [khàt] } \\
\text { 'to brush' }\end{array}$ \\
\hline 2 & $\begin{array}{l}\text { ปา [pāa] } \\
\text { 'to throw' }\end{array}$ & $\begin{array}{l}\text { ป้า [pàa] } \\
\text { 'forest' }\end{array}$ & $\begin{array}{c}\text { ป้า [pâa] } \\
\text { 'aunt' }\end{array}$ & $\begin{array}{l}\text { ปาด [pàat] } \\
\text { 'to cut' }\end{array}$ & $\begin{array}{l}\text { ปัด [pàt] } \\
\text { 'to wipe' }\end{array}$ \\
\hline 3 & $\begin{array}{l}\text { บาน [bāan] } \\
\text { 'to blossom' }\end{array}$ & $\begin{array}{l}\text { บ่า [bàa] } \\
\text { 'shoulders' }\end{array}$ & $\begin{array}{l}\text { บ้า [bâa] } \\
\text { 'to be mad' }\end{array}$ & $\begin{array}{l}\text { บาด [bàat] } \\
\text { 'to be cut' }\end{array}$ & $\begin{array}{l}\text { บัตร [bàt] } \\
\text { 'card' }\end{array}$ \\
\hline 4 & $\begin{array}{l}\text { คา [khāa] } \\
\text { 'thatch grass' }\end{array}$ & ค่า [khâa] 'price' & $\begin{array}{l}\text { ค้า [kháa] } \\
\text { 'to trade' }\end{array}$ & $\begin{array}{l}\text { คาด [khâat] } \\
\text { 'to tie a belt' }\end{array}$ & $\begin{array}{l}\text { ดัด [khát] } \\
\text { 'to handwrite', }\end{array}$ \\
\hline
\end{tabular}

\section{Test words randomized from the analogous set.}

\begin{tabular}{|c|c|c|c|c|}
\hline 1. ขา [khăa] & 13. ป้า [pàa] & 25. ค้า [kháa] & 37. ป้า [pàa] & 49. ปทา [pàa] \\
\hline 2. ปา [pāa] & 14. บาน [bāan] & 26. ค้า [kháa] & 38. ขา [khăa] & 50. บาน [bāan] \\
\hline 3. บาน [bāan] & 15. ขา [khăa] & 27. บ้า [bâa] & 39. ป้า [pàa] & 51. บ่า [bàa] \\
\hline 4. คา [khāa] & 16. บ่า [bàa] & 28. ป้า [pàa] & 40. บ่า [bàa] & 52. ป๋า [pàa] \\
\hline 5. ข่า [khàa] & 17. ข้าว [khâaw] & 29. ข้าว [khâaw] & 41. ข่า [khàa] & 53. ข่า [khàa] \\
\hline 6. ป้า [pàa] & 18. คา [khāa] & 30. คา [khāa] & 42. ด้า [kháa] & 54. ขา [khăa] \\
\hline 7. บ่า [bàa] & 19. ด้า [kháa] & 31. บาน [bāan] & 43. บ้า [bâa] & 55. لา [pāa] \\
\hline 8. ค่า [khâa] & 20. ปทา [pàa] & 32. ช่า [khàa] & 44. ด่า [khâa] & 56. ไ้าว [khâaw] \\
\hline 9. ข้าว [khâaw] & 21. ปา [pāa] & 33. ค่า [khâa] & 45. ปา [pāa] & 57. บ้า [bâa] \\
\hline 10. ป้า [pâa] & 22. ข่า [khàa] & 34. ขา [khăa] & 46. คา [khāa] & 58. คา [khāa] \\
\hline 11. บ้า [bâa] & 23. บ้า [bâa] & 35 ป่า [pàa] & 47. ข้าว [khâaw] & 59. ค่า [khâa] \\
\hline 12. ด้า [kháa] & 24. ค่า [khâa] & 36. ปา [pāa] & 48. บาน [bāan] & 60 . ด้า [kháa] \\
\hline 1. ขาด [khàat] & 5. ปาด [pàat] & 9. คาด [khâat] & 13. ขาด [khàat] & 17. คาด [khâat] \\
\hline 2. ปาด [pàat] & 6. ขาด [khàat] & 10. บาด [bàat] & 14. ปาด [pàat] & 18. ปาด [pàat] \\
\hline 3. คาด [khâat] & 7. คาด [khâat] & 11. ขาด [khàat] & 15. คาด [khâat] & 19. ขาด [khàat] \\
\hline 4. บาด [bàat] & 8. บาด [bàat] & 12. ปาด [pàat] & 16. บาด [bàat] & 20. บาด [bàat] \\
\hline 21. ขัด [khàt] & 25. ขัด [khàt] & 29. ชัด [khàt] & 33. ขัด [khàt] & 37. บัตร [bàt] \\
\hline 22. ปัด [pàt] & 26. คัด [khát] & 30. ปัด [pàt] & 34. บัตร [bàt] & 38. ขัด [khàt] \\
\hline 23. ดัด [khát] & 27. ปัด [pàt] & 31. ดัด [khát] & 35. ดัด [khát] & 39. ปัด [pàt] \\
\hline 24. บัตร [bàt] & 28. บัตร [bàt] & 32. บัตร [bàt] & 36. ปัด [pàt] & 40. คัด [khát] \\
\hline
\end{tabular}


Appendix 2 Lao tonal systems based on the literature

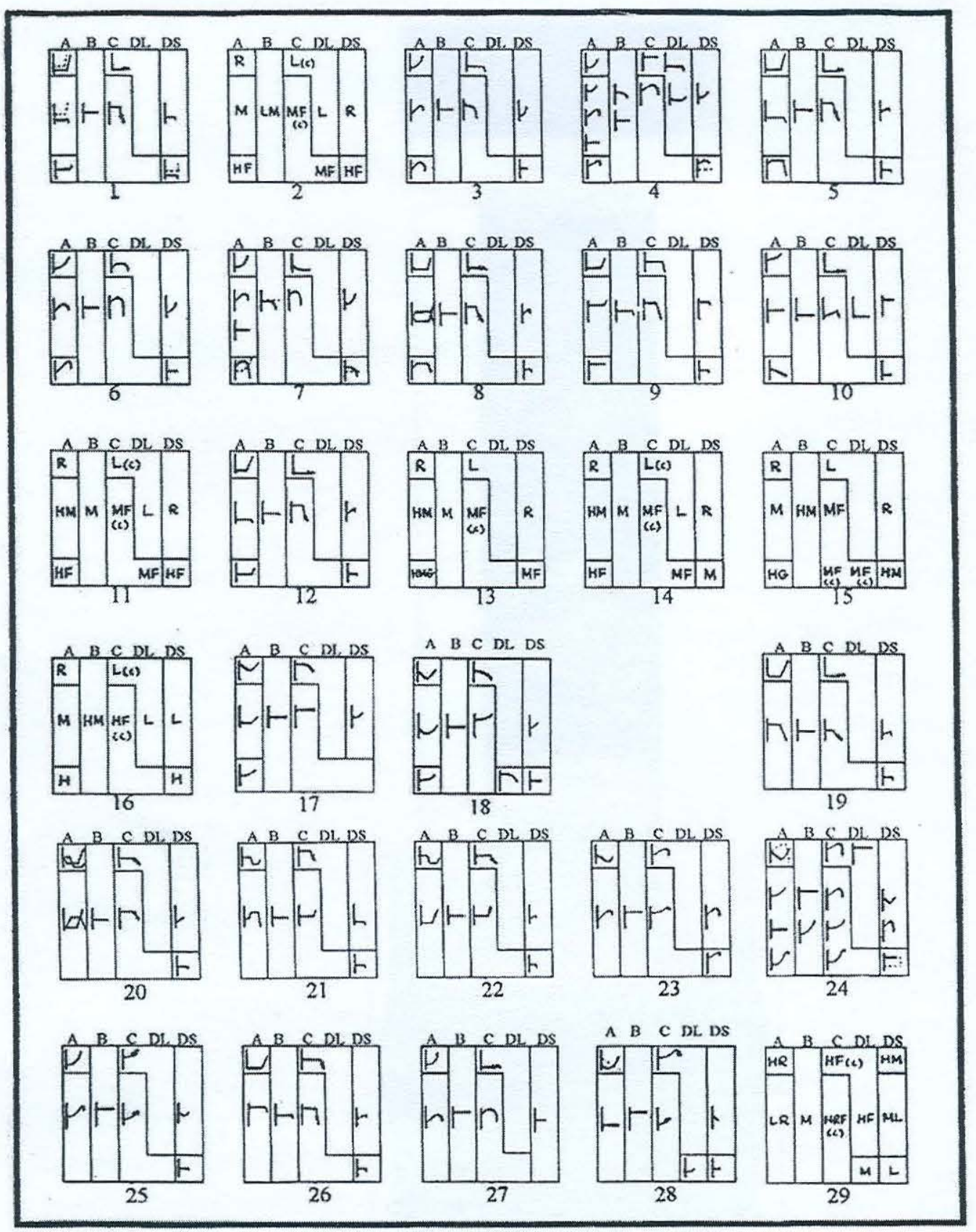


Appendix 2 (continued)

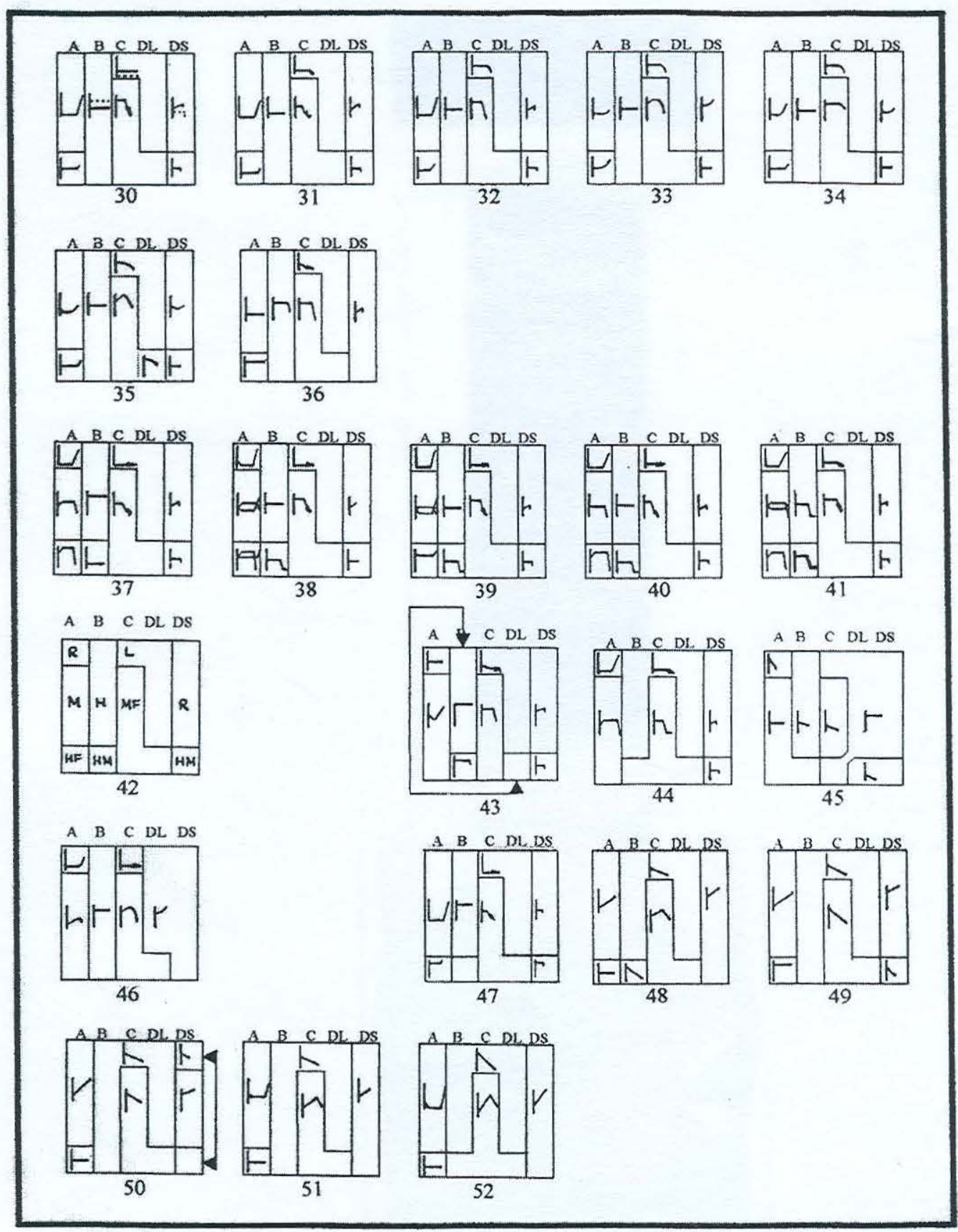


Appendix 2 (continued)
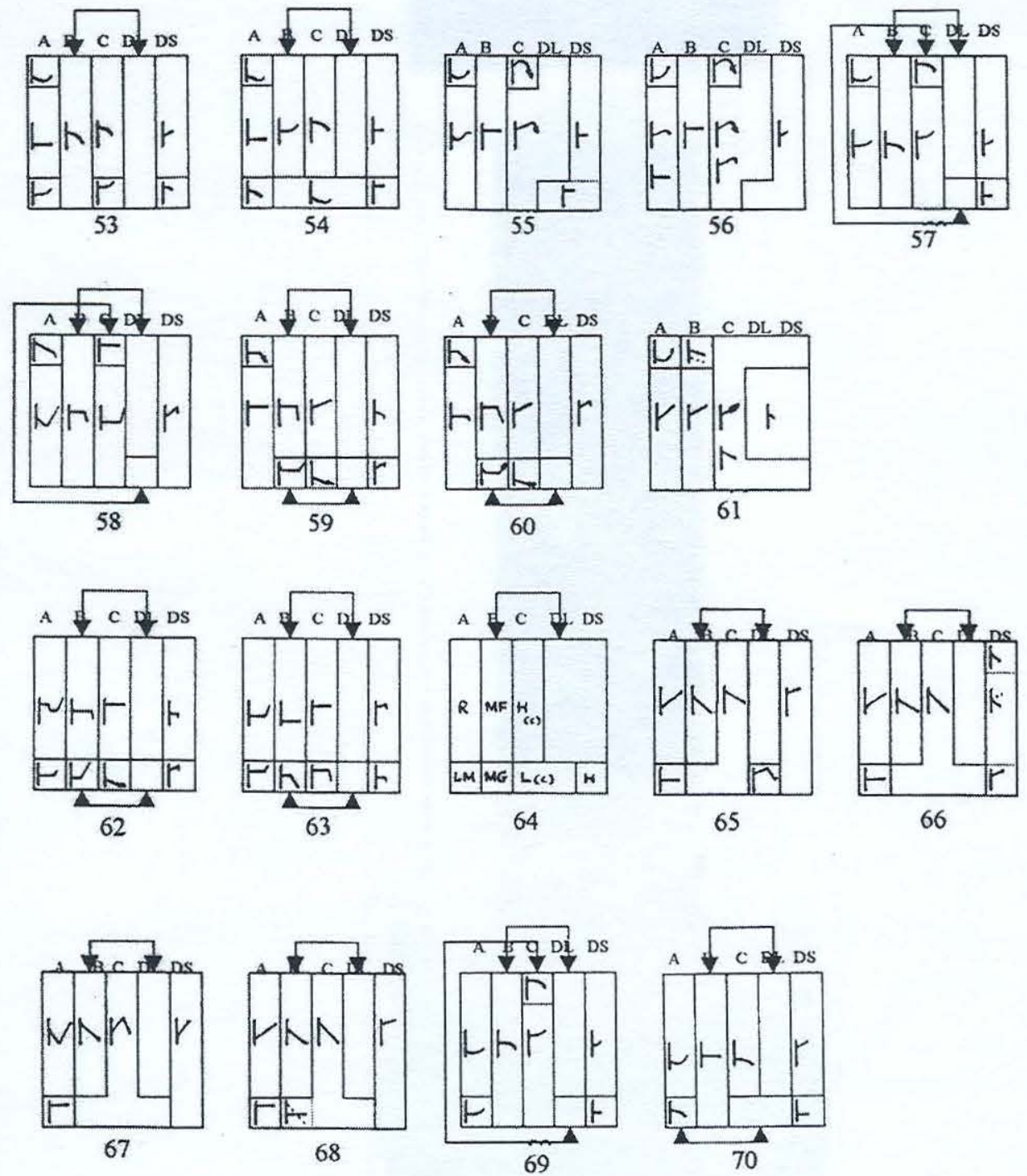


\section{Appendix 2 (continued)}

\section{Sources of Lao tonal systems}

1. Vientiane Group (Thurakhom, Chaiyaphum) (adapted from Brown, 1965)

2. Vientiane (adapted from Simmonds, 1965)

3. Lao Viang (Muang District, Nakhon Pathom Province) (Panka, 1980)

4. Lao Viang (Chai Nat, Suphanburi, Nakhon Pathom Provinces) (Wattanaprasert and Liamprawat, 1985)

5. Southern Lao Group (Ubon, Muang Samsip, Yasothon, Kam Khuean Kaeo, Pakse Bongfai, Sahatsakhan, Prachantakham, Bua Yai, Khon Kaen, Udon, Phanom Phrai) (adapted from Brown, 1965)

6. Southern Lao (Muang District, Nakhon Pathom Province) (Panka, 1980)

7. Southern Lao (Chai Nat, Nakhon Pathom Provinces) (Wattanaprasert and Liamprawat, 1985)

8. Nong Khai Group (Nong Khai Province) (adapted from Brown, 1965)

9. Nakhon Phanom (Dejvongsa and et. al. (eds.), 1972)

10. Pakse Lao (Hoonchamlong, 1985)

11. Pakse (adapted from Simmonds, 1965)

12. Thurakhom (Dejvongsa and et. al. (eds.), 1972)

13. Savannakhet (adapted from Simmonds, 1965)

14. Khong (adapted from Simmonds, 1965)

15. Repatriated Lao (adapted from Simmonds, 1965)

16. Ken Thao (adapted from Simmonds, 1965)

17. Xanakham (Vientiane) (adapted from Osathananda, 1997)

18. Phonhong (Vientiane) (adapted from Osathananda, 1997)

19. Southern Lao Group (Si Saket, Tha Tum) (adapted from Brown, 1965)

20. 1750 Luang Prabang (adapted from Brown, 1965)

21. Luang Prabang Group (Kaen Thao, Dan Sai, Loei) (adapted from Brown, 1965)

22. Luang Prabang (adapted from Brown, 1965)

23. Lao Khrang (Muang District, Nakhon Pathom Province) (Panka, 1980)

24. Lao Khrang (Chai Nat, Suphanburi, Nakhon Pathom Provinces) (Wattanaprasert and Liamprawat, 1985)

25. Lao Ngaew (Tambon Thong En, Inburi District, Singburi Province) (Chinchest, 1989)

26. Attapue (Dejvongsa and et. al. (eds.), 1972)

27. Southern Lao (Tha Tako District, Nakhon Sawan Province) (Daecha, 1987)

28. Lao Ngaew (Tambon Thong En, Inburi District, Singburi Province) (Pungpaopan, 1984)

29. Luang Prabang (adapted from Simmonds, 1965)

30. Vientiane Group (Vientiane, Lom Sak, Khon Sawan) (adapted from Brown, 1965)

31. Vientiane (adapted from Brown, 1965)

32. Vientiane (Dejvongsa and et. al. (eds.), 1972)

33. Vientiane Prefecture (Sangthong, Naxaythong, Sikhottabong, Xaithani, Chantaburi, Xaisettha, Sisattanak, Hatxaythong, Pak-Ngum) (adapted from Osatananda, 1997)

34. Thourakhom (Vientiane) (adapted from Osatananda, 1997)

35. Keo-Oudom (Vientiane) (adapted from Osatananda, 1997)

36. Lao Nue (Northern Lao) (Ban Na Lae-Luang Nam Tha) (Dejvongsa and et. al. (eds.), 1972)

37. Southern Lao Group (Roi-et, Thawatburi, Wapipathum, Non Phet) (adapted from Brown, 1965)

38. 1550 Vientiane (adapted from Brown, 1965)

39. 1700 Vientiane (adapted from Brown, 1965)

40. 1700 Southern Lao (adapted from Brown, 1965)

41. 1650 Sakon Nakhon (adapted from Brown, 1965) 
42. Roi-et (Haas, 1958)

43. Nambak (Dejvongsa and et. al. (eds.), 1972)

44. Khorat (adapted from Brown, 1965)

45. Lao Viang (Lopburi, Singburi, Saraburi Provinces) (Khanittanan, 1973)

46. Lao Viang (Tha Tako District, Nakhon Sawan Province) (Daecha, 1987)

47. Khon Sawan (adapted from Brown, 1965)

48. Lao (Nakae Village, That Phanom District, Nakhon Phanom Province) (Akharawatthakun, 1998)

49. Lao (Man Yon Village (1), That Phanom District, Nakhon Phanom Province) (Akharawatthakun, 1998)

50. Lao (Man Yon Village (2), That Phanom District, Nakhon Phanom Province) (Akharawatthakun, 1998)

51. Lao (Tan Kut (1) and Nakae Villages, That Phanom District, Nakhon Phanom Province) (Akharawatthakun, 1998)

52. Lao (Tan Kut Village, That Phanom District, Nakhon Phanom Province) (Akharawatthakun, 1998)

53. Kasi 2 (Vientiane) (adapted from Osatananda, 1997)

54. Kasi 1 (Vientiane) (adapted from Osatananda, 1997)

55. Lao Khrang (Tha Tako District, Nakhon Sawan Province (Daecha, 1987)

56. Lao Ngaew (Tha Tako District, Nakhon Sawan Province (Daecha, 1987)

57. Vientiane Lao (Naxaythong 2, Vientiane Prefecture) (adapted from Osatananda, 1997)

58. Muang Ngoi (Dejvongsa and et. al. (eds.), 1972)

59. Muang Yong (Dejvongsa and et. al. (eds.), 1972)

60. Sam Nua (Dejvongsa and et. al. (eds.), 1972)

61. Lao Viang (Nong Nae District, Chachoengsao Province (Chantanakhom and Rattanaprasert, 1983)

62. Muang Vaen (Dejvongsa and et. al. (eds.), 1972)

63. Muang Saen (Dejvongsa and et. al. (eds.), 1972)

64. Sam Nüa (adapted from Simmonds, 1965)

65. Lao (Tan Kut Village (2), That Phanom District, Nakhon Phanom Province) (Akharawatthakun, 1998)

66. Lao (Man Yon Village (3), That Phanom District, Nakhon Phanom Province) (Akharawatthakun, 1998)

67. Lao (Tan Kut (3), Non Sa-art, Man Yon Villages (4), That Phanom District, Nakhon Phanom Province) (Akharawatthakun, 1998)

68. Lao (Man Yon Village (5), That Phanom District, Nakhon Phanom Province) (Akharawatthakun, 1998)

69. Vientiane Lao (Naxaythong 1, Vientiane Prefecture) (adapted from Osatananda, 1997)

70. Vangviang (Vientiane) (adapted from Osatananda, 1997) 
Appendix 3 Majority Lao (Vientiane accent) in Nong Khai Province and minority Lao Isan in Loei Province (based on the author's findings)

\section{Majority Lao Isan in Nong Khai Province}
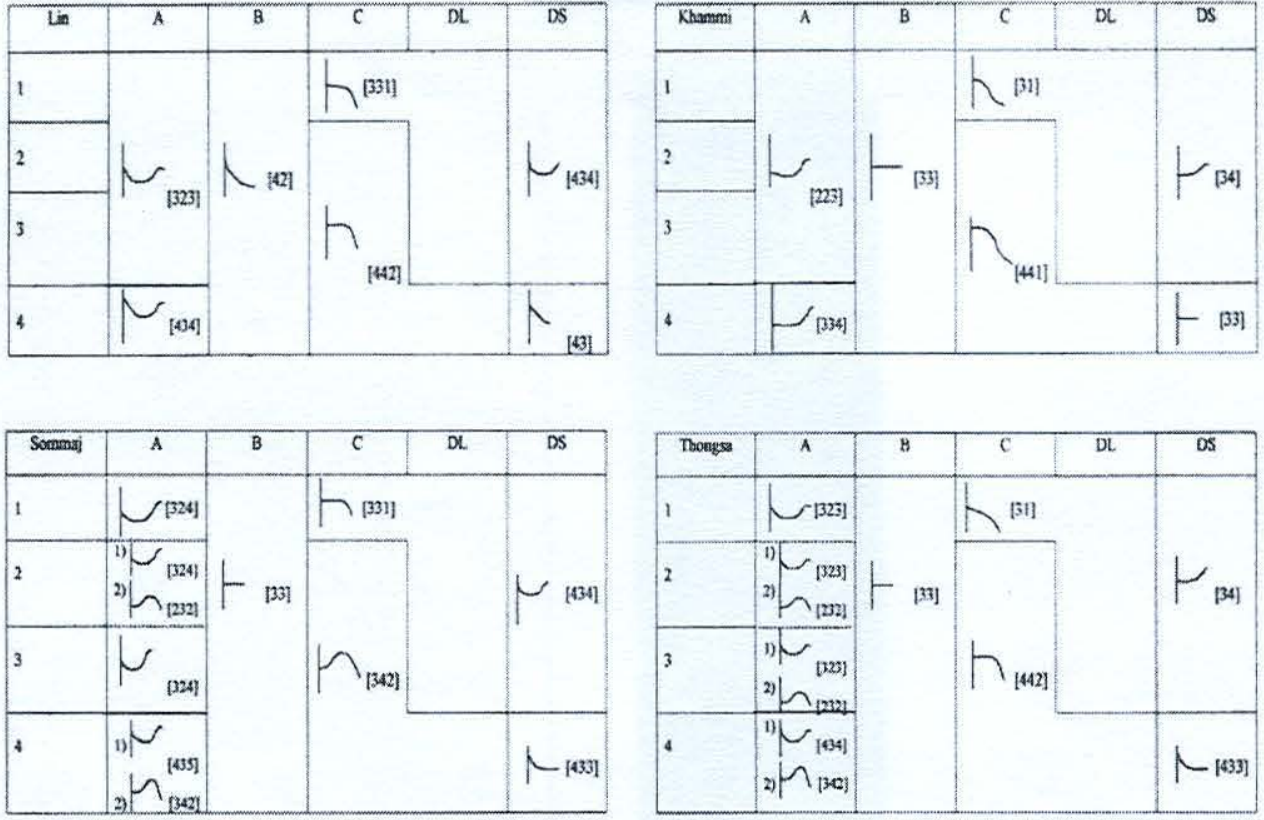

\begin{tabular}{|c|c|c|c|c|c|}
\hline Thonephente & $A$ & B & c & $\bar{D}$ & DS \\
\hline 1 & $\log _{[323]}$ & \multirow{3}{*}{$-[43]$} & (15] & & \multirow{3}{*}{$\nu_{134}$} \\
\hline 2 & [212] & & \multirow{2}{*}{$h_{143 !}$} & & \\
\hline 3 & $\mathcal{N}_{[212]}$ & & & & \\
\hline 4 & & & & & $L$ \\
\hline
\end{tabular}




\section{Appendix 3 (continued)}

2. Minority Lao Isan in T. Chiangkhan, Chiangkhan District, Loei Province

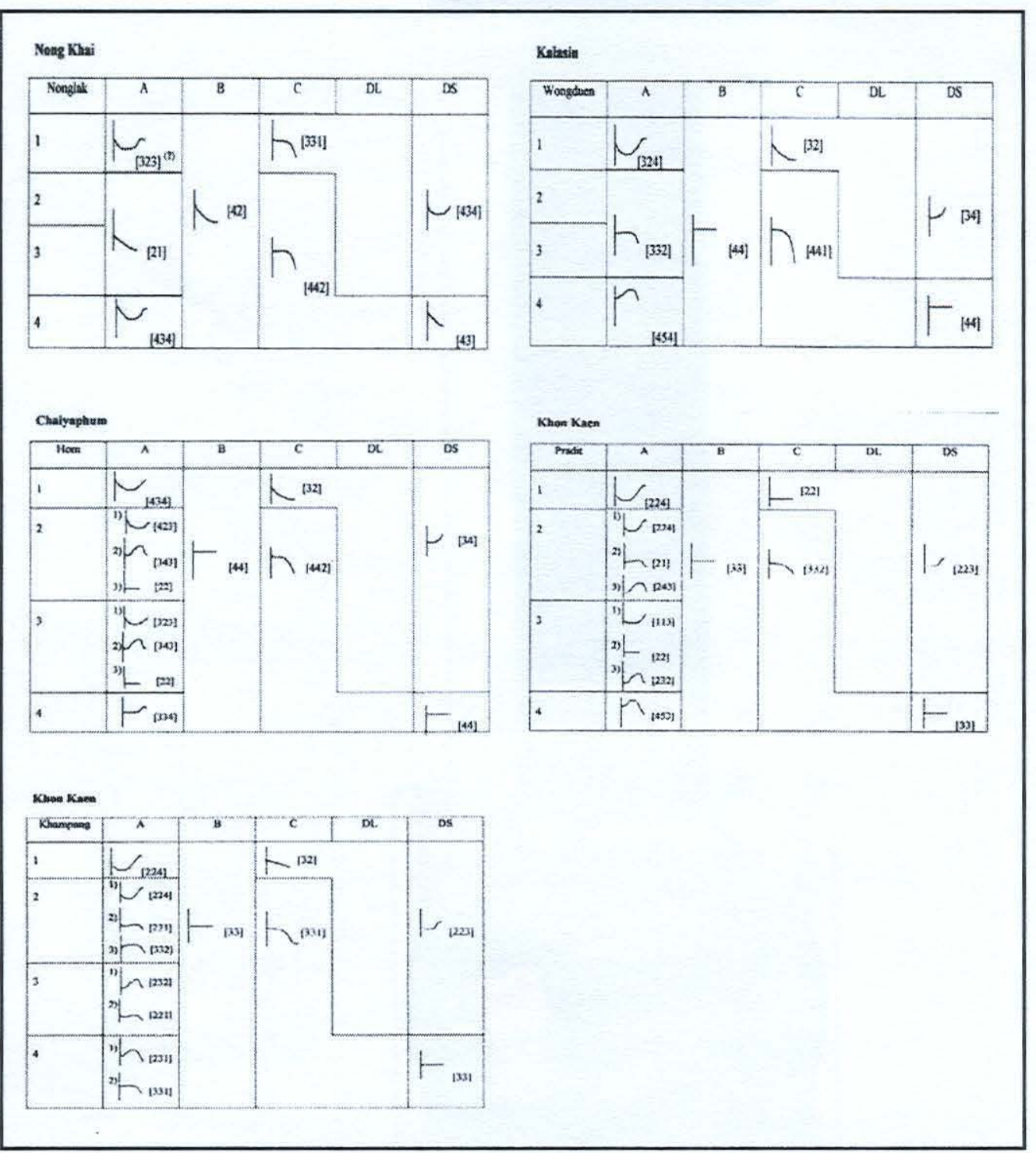




\section{Appendix 3 (continued)}

\section{Minority Lao Isan in T. Chomsri, Chiangkhan District, Loei Province}
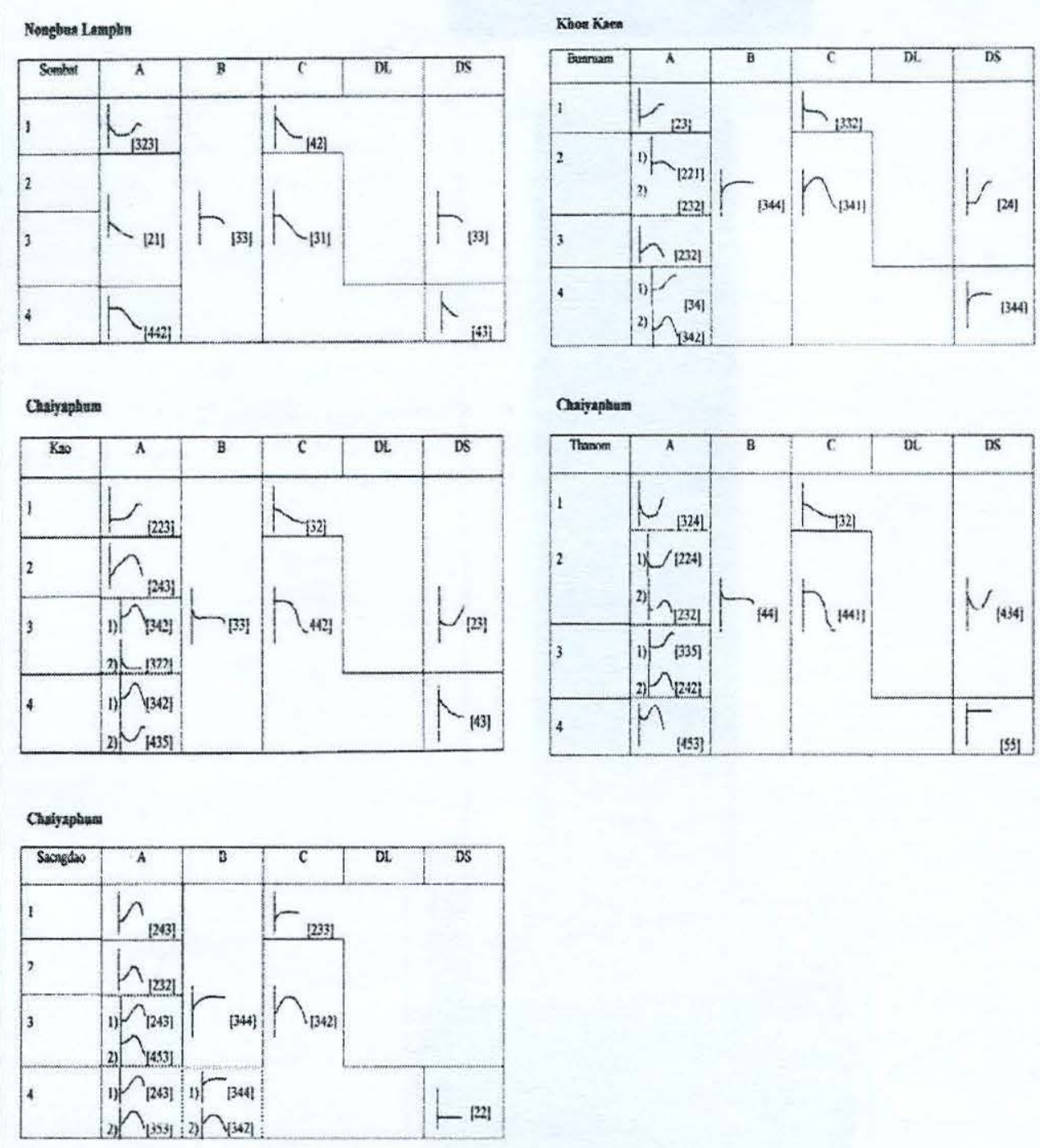